\title{
United States Supreme Court February Term 1824
}

\section{David B. Roe ${ }^{\dagger}$ and Russell K. Osgoodt}

The business of the United States Supreme Court in 1824 reflects a rich and not altogether familiar legal world. But the student pursuing a curiosity about the Court of 150 years ago starts from firmer ground than most historians, since there is one source which is contemporary, comprehensive, and learned: the ninth volume of Henry Wheaton's annual Reports of Cases Argued and Adjudged in the Supreme Court of the United States, subtitled February Term, 1824. ${ }^{1}$

The Supreme Court in 1824 was perhaps as powerful an institution as it is today, but in the public eye it was far from being as grand, as impartial, or as ultimate. The salary was poor, ${ }^{2}$ and circuit duty was so arduous that-with the exception of the Chief Justice and Justice Story ${ }^{3}$-the Justices spent relatively little of their time and effort deciding cases at the highest level. During their sitting in Washington, the Justices enjoyed few trappings of office; their courtroom was in the basement of the Senate Chamber, ${ }^{4}$ and the seven men-none of whom ever brought his wife to the capital-all lived together in a boardinghouse. ${ }^{5}$ Washington's more permanent residents were far more comfortable, and the President maintained a "regal" mansion. ${ }^{\circ}$ The Justices were compensated in part by their status as social lions. Their short term in the capital, less than two months, was the high point of the Washington social season, and those who chose to, particularly the young and energetic Justice Story, made the most of it, dining

$\dagger$ Member, California Bar.

H Member, Massachusetts Bar.

1. Wheaton was the Court's first official reporter, appointed under the Act of Mar. 3 , 1816, 3 Stat. 376. He was also the first to undertake serious commentary and analysis of the decisions he reported. See, e.g., the introduction and annotations to his first volume, 14 U.S. (1 Wheat.) (1816).

2. In 1824 the Chief Justice earned $\$ 5,000$, the Associates $\$ 4,500$. During the decade before 1819, Congress had refused the Justices a badly needed raise because of displeasure over controversial decisions. See G. DunNe, Justice Joseph STORY AND ThE RISE OF THE SUPREME CoURT 178 (1970).

3. In his 34 years on the Supreme Court, Marshall wrote almost half of the 1100 opinions delivered. Pollak, Introduction to I The Justices of THE United STATES Supreme Court, Their Lives and Major Opinions at x (L. Friedman \& F. Israel eds. 1969) [hereinafter cited as LIVES OF THE JUSTICES]. Story's erudition and output were legendary, and at least once they provoked a fellow Justice to record his annoyance in an opinion. See G. DUNNE, supra note 2, at 169.

4. 1 C. Warren, The Supreme Court in United States History 460-63 (1926).

5. Id. at 473. This arrangement made possible the service of Justice Gabriel Duvall, who was quite deaf and could hear nothing at oral argument. Id. at 797. Fellow Justices explained the cases to him in the privacy of their boardinghouse.

6. G. DuNNE, supra note 2, at 125 . 
frequently at the White House and appearing there, at least for formal affairs, dressed in judicial robes. ${ }^{7}$

Washington, however, was not the center of the world, nor was a seat on the Supreme Court necessarily the pinnacle of a lawyer's career. Justice Smith Thompson wavered for months before agreeing to accept his seat, and five years later he saw no barrier to running for the governorship of the state of New York while continuing to sit as a Justice. ${ }^{8}$ Justice William Johnson, appointed at age 32 by Jefferson, spent several subsequent years trying to arrange a post for himself as tax collector of Charleston, 9 which would have yielded twice the salary. Story himself, appointed only after three other nominees had turned down the job, more than once considered leaving for private practice, and during his tenure he pursued numerous outside interests. Among other activities which apparently provoked no suspicion of conflict of interest, he exercised an influence in Massachusetts politics, marketed official reports of the decisions in his circuit, and served as president of a bank.10

The Supreme Court bar in 1824 was a small group of lawyers who knew each other and the Justices intimately; they were likely to see the latter as frequently at dinner as in court. ${ }^{11}$ Henry Clay, for example, had trained in the Richmond law office of Justice Bushrod Washington, and the story was told that one day while arguing before the Court, he reached out and helped himself to a pinch of snuff from Justice Washington's snuff box. ${ }^{12}$ There were antipathies too, and in one famous incident Justice Johnson delivered a long tirade in open court, ridiculing the argument of the leading member of the bar; the latter had to be forcibly restrained. ${ }^{13}$ The man in the most delicate position was Henry Wheaton, simultaneously the Court's reporter, a leading advocate, a conspicuous social figure, and himself a disappointed candidate for a seat on the Court. ${ }^{14}$ Wheaton was particularly

7. See 1 C. WARREN, supra note 4, at 471-73.

8. See Dunne, Smith Thompson, in Lives of THE JUSTICEs, supra note 3, at 478; G. DuNNE, supra note 2, at 281.

9. G. DUNNE, supra note 2, at 170 .

10. Id. at $77-80,91,106,120,129$.

11. See 1 C. WARREN, supra note 4 , at 471-73.

12. Morgan, William Johnson, in Lives of THE Justices, supra note 3, at 247.

13. G. DUNNE, supra note 2, at 200. Johnson was described as irascible by contemporaries, and he nursed a particularly sharp feud with Justice Story throughout their joint tenure on the bench. Id. at 168-70, 198-202. In 1824 Johnson had snide comments for Henry Wheaton. See 22 U.S. (9 Wheat.) at 718.

14. See E. BAKER, HeNRY WhEATON 36, 62 (1937). Wheaton was also an active politician in New York and tried to play kingmaker both in New York and national politics. Id. at 47-50, 62. He "made no secret of the duality of his callings" advertising his reporter status in announcements of his availability as a counselor before the Supreme Court. G. DUNNE, supra note 2 , at 199 . 
close to Justice Story, whom he frequently solicited for glosses, headnote material, and legal business, and the official reports bear some of Story's touches. ${ }^{25}$

The dominant political issue in 1824 was the balance of power between federal and state governments, the importance of which had been re-emphasized in the battles over the Missouri Compromise in 1820. That 1824 was a presidential election year did nothing to lessen popular interest. ${ }^{16}$ On the central issue, the Supreme Court found itself firmly identified with the Federalists ${ }^{17}$-even though five of its seven members had been appointed by Republican presidents ${ }^{18}$-and consequently under bitter attack, both in individual state legislatures ${ }^{10}$ and in Congress. The primary target was the Court's power to review decisions of state courts under $\$ 25$ of the Judiciary Act of 1789 , and in 1824 the House of Representatives was actively considering the repeal of $\S 25 .{ }^{20}$ There were also proposals that state laws could be declared unconstitutional only by a five-vote majority, and that the Justices be forced to deliver opinions seriatim. ${ }^{21}$

15. G. Dunne, supra note 2, at 199-200, 323-24. Dunne describes Story as a de facto joint venturer with Wheaton in the latter's reports.

16. In November, John Quincy Adams defeated Andrew Jackson for the presidency even though Jackson won the popular vote. Major participants in the politics of nomination included Henry Clay, Smith Thompson, and Henry Wheaton.

17. From 1816 to 1823 , the Court handed down a famous and controversial stream of decisions, all expanding federal power at the expense of the states: Martin $v$. Hunter's Lessee, 14 U.S. (4 Wheat.) 304 (1816); McCulloch v. Maryland, 17 U.S. (4 Wheat.) 316 (1819); Dartmouth College v. Woodward, 17 U.S. (4 Wheat.) 518 (1819); Sturges v. Crowninshield, 17 U.S. (4 Wheat.) 122 (1819); Cohens v. Virginia, 19 U.S. (6 Wheat.) 264 (1821); and Green $v$. Biddle, 21 U.S. (8 Wheat.) 1 (1823). Two more great cases were added to the series in 1824, Gibbons v. Ogden, 22 U.S. (9 Wheat.) 1; and Osborn v. The Bank of the United States, 22 U.S. (9 Wheat.) 738. See generally C. Haines, The Role of THE Supreme Court in American Government and Politics 1789-1835, at 337-497 (1944).

18. Only John Marshall and Bushrod Washington had been appointed before Thomas Jefferson became President in 1801, yet the Court was a remarkably cohesive-and Federalist-unit under the leadership of the Chief Justice. Except for Smith Thompson, who took his seat in 1824, the members of the Court had been together since 1812, and perhaps they had taken the opportunity to achieve a smooth working relationship. The only maverick, and the only real source of Republican views, was William Johnson, and his political position was less consistent than his party would have liked.

Apart from Johnson and the unknown Thompson, the Associate Justices in 1824 appeared to antagonists to be thoroughly under the Chief Justice's influence. Washington, the only other Federalist, was almost superhumanly loyal to Marshall, disagreeing with him on a vote only three times in 29 years. Thomas Todd and Gabriel Duvall, dismissed by their biographers as respectively "one of the least known" and "probably the most insignificant" of all the Supreme Court Justices who ever sat, showed little independence or assertiveness. And Joseph Story, though thoroughly independent and vigorous, had wholly abandoned his original and tentative Republican allegiance. See generally Lives of THE JUSTICES, supra note 3 .

19. See generally C. HAINes, supra note 17 , at 463.97 .

20. $I d$, at 501-02.

21. Id. at $485-87,512$. The point of the seriatim proposal, which had the backing of both Jefferson and Madison, was the suspicion that Marshall's powerful opinions masked internal dissension on the Court which individual opinions would reveal. Id. at 375.77, $517 \& \mathrm{n} .57$. It was probably hoped that forcing each Justice to offer his own explanation of a decision would diminish Marshall's influence within the Court and dilute his impact on the public mind. Until Marshall became Chief Justice, seriatim opinions were the normal practice, and they remained so in state courts. See id, at 517. 
Of the Supreme Court's decisions in the 1824 term, by far the best known is Gibbons $v$. Ogden, ${ }^{22}$ a case which needs no explanation. The subsequent history of Gibbons as a tool for federal economic regulation is so familiar, however, that the actual case is rarely considered in the setting in which it was decided. A fresh look at the other cases of its year may help to provide the necessary context. Because the Court's jurisdiction was largely appellate, there was little control of the docket, and the cases of the 1824 term present a broad array.

\section{Salt Water Commerce}

Maritime cases formed a large and steady part of the Supreme Court's work in the 1820's; in 1824, there were nine such cases. The Constitution granted exclusive jurisdiction over "admiralty and maritime" causes to the federal courts, ${ }^{23}$ and from the beginning it was assumed to be a major piece of judicial business. When the draftsmen of the Judiciary Act of 1789 vested original jurisdiction over admiralty matters in the District Courts, ${ }^{24}$ they considered it to be "the real meat" of the jurisdictional allotment to those courts. ${ }^{25}$ On the path from District to Circuit to Supreme Court, the only real obstacle was the jurisdictional amount, and admiralty cases tended to involve well more than the $\$ 2,000$ required for the final step of appeal (by writ of error) to the Supreme Court. ${ }^{26}$ Moreover, the scope of admiralty jurisdiction had been very broadly interpreted to cover "all maritime contracts, torts, and injuries. The latter branch [torts] is necessarily bounded by locality; the former extends over all contracts . . . which relate to the navigation, business, or commerce of the sea."27 That classic statement, delivered in 1815 by Justice Story while he was sitting on circuit in Boston, was never formally adopted by the Supreme Court, but all of the Justices in 1824 apparently agreed with its tenor. ${ }^{28}$ The broad jurisdiction brought a wealth of new legal issues, since shipping

22. 22 U.S. (9 Wheat.) I (1824).

23. U.S. CoNST. art. III, $\$ 2$.

24. Act of Sept. 24,1789 , ch. $20, \$ 9,1$ Stat. 73. Admiralty practice permitted essentially a trial de novo in the circuit court, in the court's discretion; and it contemplated the taking of new evidence even by the Supreme Court. See Act of Mar. 3, 1803, ch. 40, 2 Stat. 244.

25. 1 J. Goebel, Jr., History of the Supreme Court of the United States: AntecedENTS AND BEGINNINGS To 1801 , at 474 (1971).

26. Act of Mar. 3, 1803, ch. 40, 2 Stat. 244.

27. DeLovio v. Boit, 7 F. Cas. 418 (No. 3,776) (1815).

28. See, e.g., The Merino, 22 U.S. (9 Wheat.) 391, 402 (1824). The jurisdiction was restricted to tidal waters the following year in The Thomas Jefferson, 23 U.S. (10 Wheat.) 428 (1825). One of the antifederal proposals of the Kentucky legislature in 1824 was just such a limit on admiralty jurisdiction, see G. DUNNE, supra note 2, at 215. See generally p. 772 supra. 
was the core of American commerce in the early 19th century before the great westward expansion began. And yet ordinary commercial questions were the least of the problems in the admiralty rases before the Court.

Volatile international issues underlay all but one of the Court's 1824 maritime cases, and the foremost issue was the slave trade. The traffic in human beings, which had been almost universally tolerated through the end of the 18 th century, ${ }^{29}$ was being actively resisted in 1824 by the United States and Great Britain, and every major European country had made a formal declaration opposing it. American legislation against the trade had begun in 1794 with a prohibition against the participation of U.S. citizens in the trade from an American base. ${ }^{30}$ Congress later prohibited participation of United States citizens in the slave trade anywhere in the world, ${ }^{31}$ and prohibited importation of slaves into the United States by citizens and ships of any nationality. ${ }^{32}$ In 1820 Congress made the shipping of slaves an act of piracy, and therefore punishable by death ${ }^{33}$ As the official attitude hardened, so did public opinion, and by 1824, although "the American flag had vanished from the slave trade," 34 President Monroe's government was under pressure to force all other nations to stop as well. The major offenders were Spain and Portugal, who continued to shelter most of the trade under their flags.

The problem for nations opposing the slave trade was not how to handle their own ships, but what to do with those of foreign sovereigns. If every nation involved were willing and able to patrol its own coasts and the west coast of Africa, the slavers could have been stopped without international incident. Short of that impossibility, effective enforcement required that one nation's cruisers be able to stop and search the ships of others. Britain, the strongest naval power, had cruisers patrolling the African coast which stopped most ships with impunity, but the British could not interfere with American flag vessels without risking reprisals from a naval power nearly its equal. After the War of 1812, Americans were particularly touchy. As a result, slavers discouraged British interference by sailing under false

29. See, e.g., The Antclopc, 23 U.S. (10 Whcat.) 66, 116 (1825); cf. 1 C. WARREN, supra note 4 , at 585 .

30. Act of Mar. 22, 1794, ch. 11, 1 Stat. 347 .

31. Act of May 10, 1800, ch. 51,2 Stat. 70.

32. Act of Mar. 2, 1807, ch. 22, 2 Stat. 426; Act of Apr. 20, 1818, ch. 91, 3 Stat. 450.

33. Act of May 15, 1820, ch. 113, $\$ \$ 4.5,3$ Stat. 600 .

34. W. Howard, hmerican Slavers and tile Federal Law 30 (1963). 
American flags and papers. ${ }^{35}$ The obvious and effective solution would have been a British-American treaty allowing reciprocal rights of search, and as the Supreme Court sat in 1824 the prospects for such a treaty looked promising. In 1823, the House of Representatives had overwhelmingly approved a resolution urging Monroe to negotiate with the maritime powers "for the effectual abolition of the African slave trade," 36 and on March 13, 1824, British and American negotiators agreed on the text of a comprehensive anti-slave-trade treaty including reciprocal visit and search rights, which the British Parliament passed within the month. Only after the Court's term ended did the Senate decide not to ratify the treaty, putting. an end to any hope for a quick abolition of the trade. ${ }^{37}$

In the meantime, as the negotiations progressed in 1824, there remained the legal problem of captured foreign-flag slavers, who were not trying to import slaves into the United States. Only if the slave trade violated international law could an American court assert jurisdiction, and on that crucial question there was passionate debate. After some indecision, ${ }^{38}$ the British High Court of Admiralty had apparently decided in 1817 that slavery did not violate international law. ${ }^{39}$ Justice Story on circuit had decided the opposite in 1822.40 The question, though not directly addressed by the Court in $1824,{ }^{41}$ was obviously ripe, and it was on the minds of the Justices.

Though admiralty questions combined arcane learning with diplomatic delicacy, the Supreme Court of 1824 was reasonably well equipped to treat them. The resident authority (as in other fields) was Justice Story, whose prior law practice in Massachusetts had been largely composed of admiralty cases ${ }^{42}$ and who had edited and provided American annotations for a leading British treatise on the subject. ${ }^{43}$ The Court also leaned on its bar for instruction in interna-

35. American papers and flags offered protection from British cruisers only as long as they were belicved. If they were suspected of being fraudulent, their holders could be taken to an American court for violating the U.S. Ship Registry Act. American justice for slavers was dreaded, and as a result it was common for a suspected slaver under British investigation to throw its American papers overboard. $I d$. at 20.

36. 40 ANNALS OF ConG., 1147.55 (1823).

37. See generally S. Benis, JoHn Quincy Adams AND the Foundations of AMERICAN Foreign PolicY 423-33 (1949); W. Howard, supra note 34, at 13-27.

38. The precedents are discussed in the arguments of counsel in The Antelope, 23 U.S. (10 Wheat.) 66, 77-105 (1825).

39. Le Louis, I Dods. 260, 165 Eng. Rep. 1464 (Adm. 1817)

40. United States v. The La Jeune Eugenie, 26 F. Cas. 832 (No. 15,551) (1822)

41. It was decisively settled, in favor of the British view, the following year in an opinion by Marshall. The Antelope, 23 U.S. (10 Wheat.) 66 (1825).

42. G. DUNNE, supra note 2, at 101 .

43. C. Abbott, A Treatise on the Law Relative to Merchant Ships and Seamen, with The Copious ANnotations of Joserh STORY (1822) [hereinafter cited as AbBotT's LAW of SHIPPING]. 
tional law matters. Daniel Webster, Attorney General William Wirt, David B. Ogden, William H. Winder, and Henry Wheaton were particularly helpful. ${ }^{44}$

\section{A. The Slave Trade}

The Margare ${ }^{45}$ was a classic slave trade case, and like most such, it involved no actual slaves. Nor was there any proof that the ship which had been seized and brought to court was likely to be used in the forbidden trade; it bore none of the characteristic trappings of the outfitted slaver. The Margaret, originally American-owned, had sailed from its home port of Baltimore to Havana, where it had taken on Spanish papers, a Spanish captain, and apparently a Spanish owner. When it was stopped by a revenue cutter on the trip back to Baltimore, its crew proffered its old American papers. The Spanish captain masqueraded as a passenger and hid the Spanish documents, but he and they were discovered and the Margaret was seized. ${ }^{46}$

The Ship Registry Acts, which governed the official registering of American vessels, provided that when a registered American ship was sold to a foreign owner, its registration certificate had to be surrendered to an American tax collector. ${ }^{47}$ The penalty for noncompliance was forfeiture of the ship. ${ }^{48}$ If the Margaret had been sold to a Spaniard, as it appeared, its continuing possession of its American certificate violated the statute. Haley, the ship's American owner, offered an ingenious defense. He admitted the transfer of title to a Spanish subject and the ship's "assumption of a Spanish character," but he argued "that it was a mere colourable transfer, for the purpose of evading the Spanish revenue laws, the real American ownership not having been bona fide changed." $₫ 9$ Since ownership had not really changed, the registry act ought not apply. The district court in Baltimore, and subsequently the circuit court, agreed.

Justice Story easily refuted Haley's argument, both on the language of the statute and on its underlying policy. ${ }^{50} \mathrm{He}$ observed that Haley could use his two sets of papers to evade American revenue laws as

44. See 1 C. WARREN, supra note 4, at 567. As a reporter, Wheaton had a special interest in admiralty, especially prize cases. E. BAKER, supra note 14 , at 31 . See yenerally Appendix, Note II at 14 U.S. (1 Wheat.) 494-506 (1816), and the appendix notes in 17 U.S. (4 Wheat.) appendix at 23-59 (1819), and 18 U.S. (5 Wheat.) appendix at 52-158 (1820). Until 1819 Wheaton had been Chief Judge of the Marine Court. E. BAKER, supra, at 24-25.

45. 22 U.S. (9 Wheat.) 421 (1824).

46. Id. at $422-23$.

47. Act of Dec. 31, 1792, ch. 1, \$ 7, 1 Stat. 287.

48. Id. $\$ 16$.

49. 22 U.S. (9 Wheat.) at 423.

50. Id. at 424 . 
easily as he admittedly was evading Spanish laws. By construing the statute broadly, Story derived "a strict and plain rule" that all title transfers came under the registry provisions. ${ }^{51}$ But though his reasoning was wholly adequate for the case, Story was not satisfied. He went on at surprising length about the scope and strictness of the congressional intent, introduced a lecture on the breadth of admiralty jurisdiction, ${ }^{52}$ and in pure dictum issued a reminder that in these cases owners who claimed innocence of such shady transfers bore the burden of proof. ${ }^{53}$ The impression given to the reader-and to lower courts-was that the United States should enforce its registry acts ferociously and split no hairs.

Story was rarely succinct, but The Margaret was a remarkably simple case, and prolixity alone does not explain the tone of the opinion. The more likely explanation is the unmentioned but pervasive presence of the slave trade. Whatever the Margaret's purpose, every judge of the time knew that hundreds of American-built ships passed into the slave trade along the Margaret's route, being sold to Spanish and Portuguese owners at Havana or Bahia. ${ }^{54}$ The fast Baltimore clippers were a favorite slave ship, and the Baltimore shipbuilders did a thriving business. ${ }^{65}$ American registration papers were much in demand by foreign slave ship owners, for the relative immunity from British seizure they provided, and customhouse perjury to obtain those papers was rife.50 What Story had in mind as he sought to put teeth in the ship registry acts was not some petty cheating on shipping taxes, but the profitable $e^{57}$ and morally outrageous ${ }^{58}$ trade in slaves. ${ }^{59}$

51. Id. at 425. Story's broad construction of the statute is in contrast with his much less expansive reading of the Statute of William, 11 and $12 \mathrm{Wm} .111$, ch. 6 in M'Creery's Lessee v. Somerville, 22 U.S. ( 9 Wheat.) 354 (1824).

52. Id. at $426-29$.

53. Id. at 425-26.

54. W. HowaRD, supra note 34 , at 30 .

55. Id.

56. "Perjury permitted many an American vessel to be converted into foreign property while sailing under American registry, immune to British seizure." Id. at 20.

57. See id. at 2, 52-53.

58. Justice Story's son, William Wetmore Story, reported that in 1819 the Justice "had made up his mind that it was his duty, judicially and morally, to exert his utmost powers to procure the annihilation of this trade..." 1 W. STORY, LIFE AND LETTERS OF JOSEPH STORY 348 (1851).

59. In The St. Jago de Cuba, 22 U.S. (9 Wheat.) 409 (1824), slave trading again was the offense, but what reached the Supreme Court was merely an unrelated and novel point of admiralty law. Like The Margaret, the ship in this case was owned by United States citizens in Baltimore, who sent her to Cuba and arranged a colorable conveyance to Spaniards; she was then fitted out for the slave trade. On the way to Africa the ship was pursued by hostile vessels, damaged, and forced to put into Baltimore to refit. There she was seized and condemned for violating the "fitting out" provisions of the Slave Trade Acts. As in The Margaret the District Court found the colorable sale did not remove the American ownership, and "fitting out" was broadly construed and held to apply. The Supreme Court upheld condemnation.

The remaining question, which occupied Justice Johnson in his opinion for the Court, 
The Emily and The Caroline ${ }^{60}$ also involved no slaves, but it did involve direct violations of the Slave Trade Acts. To be effective, those laws had to prohibit more than the actual shipping of slaves, since no laden slave ship wasted any time getting clear of the African coast or unloading in the Americas, and only along the coasts did patrols have any real chance of finding and capturing slavers. However, empty slavers did spend time lingering off Africa, waiting for a load of slaves to be assembled and looking for a good moment to transfer them on board. ${ }^{01}$ The legal response, contained in the earliest Slave Trade Act, was to condemn and forfeit all ships which were fitted out with slave trade equipment, and also to forbid the act of outfitting. ${ }^{62}$ Slave ships were therefore legally vulnerable from the moment they took on a slaver's character.

Though there were arguments about what amounted to an outfitting for slave shipping, the essentials were distinctive and hard to hide. Most obvious was a slave deck (or enough lumber to build one), which was installed between the main deck and the hold and on which the slaves were carried; no ordinary small merchant ship needed such a deck. ${ }^{63}$ Slavers also needed huge amounts of food and water, unusual amounts of medicine to prevent epidemics among the weakened and unimaginably crowded slaves, ${ }^{64}$ weapons, iron gratings over the hatches, and perhaps shackles. ${ }^{65}$ It was much more common to capture a slaver in the process of outfitting, or one equipped but empty, than it was to catch one full.

Both the Emily and the Caroline had been seized in Charleston,

concerned the repairers, who claimed a materialmen's lien against the ship (in fact, against the proceeds of the judicial sale) for the work they had done.

Materialmen's liens were familiar in English admiralty law, and though the Supreme Court had not passed on the point before 1824, the liens presumably existed in American law as well. See ABBotr's LAw of SHIPPING, supra note 43, at 160 n.l. There was also an exception to the lien rule, of much more dubious heritage, which held that in a vessel's home port a materialmen's lien did not exist except by operation of state law, which law Maryland did not have. See The General Smith, 17 U.S. ( 4 Wheat.) 438,442 (1819). Finally,
it was assumed that if a repairer had a valid lien, that lien was not displaced by forfeiture as long as the repairer had not connived in the illegal activity. 22 U.S. (9 Wheat.) at 417. What Johnson tried to do, in a nice demonstration of the temptations and dangers of anthropomorphism in admiralty practice, was to give the rationale for the rule and exception. He had to stretch to do it, since in the case before him he found no innocent repairer or supplier to whom the rule and exception might have applied. 22 U.S. (9 Wheat.) at 415-20. Johnson's explanation turned on the suggestion that "home port" was a subjective state of mind rather than a fixed datum. Inadvertently, he thereby "opened endless possibilities of refinement in which the courts wallowed for generations." See generally G. Gilmore \& C. BLACK, THE LAw OF ADMIRAlty 527-29 (1957).

60. 22 U.S. (9 Wheat.) 381 (1824).

61. W. HowARD, supra note 34 , at 18 .

62. Act of Mar. 22, 1794, ch. 11, \$ 1, 1 Stat. 347.

63. W. HowARD, supra note 34 , at 16-17.

64. See id. at $17 ; 1$ W. STORY, supra note 58, at $344-45$.

65. W. HowARD, supra note 34 , at 15,16 . 
as they were in the process of fitting out for the slave trade. Their main defense, relying on an 1813 Supreme Court ruling in the same case, $^{6 B}$ was that the libel of information drawn against them was imperfect in that it combined two charges in the alternative within one count. ${ }^{67}$ Armed with Justice Story's gloss of the earlier ruling, ${ }^{68}$ Justice Thompson had no trouble disposing of the defense. He also swept away the owners' claim of insufficient proof-in that neither ship had finished being fitted out-with a broad interpretation of the statute and a lecture on its purpose. ${ }^{60}$ The opinion ${ }^{70}$ is a typical example of hearty judicial support for the anti-slave trade campaign.

Another jurisdictional slave trade case, The Merino, ${ }^{71}$ was a judicial footnote to the military and diplomatic daring of Andrew Jackson and James Monroe. In 1818, as her Latin American colonies fought for independence, Spain had only nominal control over her province of Florida. The United States government had wanted the territory for years, and was particularly annoyed after the War of 1812 that British provocateurs had remained in Florida and encouraged the Seminole Indians to skirmish with Americans across the border. Jackson had marched into West Florida during the war, and in 1818 he saw his chance again; he invaded the same area, took over the garrison at Pensacola, and promptly executed two of the provocateurs, Ambrister and Arbuthnot. ${ }^{72}$ Almost incidentally, his men also seized three slave

66. The Brig Caroline, II U.S. (7 Cranch) 496 (1813). The earlier ruling had struck down a libel of information which had combined legal and illegal alternatives in one count, 11 U.S. (7 Cranch) at 500. The Court had clearly limited its ruling not to apply to the kind of count which had been drawn on remand-not in the body of its opinion, but in an unusual Note which Justice Story had supplied to the reporter, William Cranch, and which Cranch had inserted in the front of the 1813 volume of reports. See id. at xv; 22 U.S. (9 Wheat.) at 387.

67. One charge was "fitting out" for the slave trade; the other was "causing the vessel to sail" in the slave trade. 22 U.S. (9 Wheat.) at 387 . Both were violations of $\$ 1$ of the 1794 act and of the nearly identical $\$ 2$ of the 1807 act. See notes 30,32 supra.

68. See note 66 supra.

69. 22 U.S. (9 Wheat.) at 388-90.

70. The Emily and The Caroline was Justice Thompson's first opinion for the Supreme Court, and perhaps an easy case was assigned to him for that reason. But though the out. come is clear, his effort fails to explain some small mysteries: for one, the 14-year lapse between seizure and final adjudication (11 years since the first Supreme Court considera. tion of the case). For another, the Caroline at least had had an interesting career after its 1810 seizure; its owner had gotten rid of the offending fitments when told they were illegal, had then sailed the ship to Havana and sold it to a Spaniard who proceeded to fit it out once again for the slave trade. See The Brig Caroline, 11 U.S. (7 Cranch) 496, 498 (1813). Whether any proceedings had been instituted based on those later facts, and how the Caroline had once again come into the custody of the Circuit Court in South Carolina, Thompson did not mention.

71. The Merino, 22 U.S. (9 Wheat.) 391 (1824).

72. See generally S. BEMIs, supra note 37, at 313-15. There is some question whether Monroe authorized Jackson to invade Florida, see id. at $314 \mathbf{n . 3 9}$, but he was clearly pleased with the results and used Jackson's reputation to diplomatic advantage. Id. at 313, 316. 
ships, loaded with slaves, which had made the supposedly safe voyage from Cuba to Pensacola. By the time the case reached the Supreme Court, Jackson was a leading contender for the presidency, and by the end of the year he had won the popular vote (though not the office) in the national election.

The seized ships had been taken to the District Court of Alabama for trial, and the owners raised the obvious jurisdictional issues. The Judiciary Act of 1789 conferred jurisdiction over seizures on district courts "where the seizures are made . . . within their respective districts, as well as upon the high seas"; they claimed their ships had been seized not on the high seas or within the waters of a district, but within the waters of a foreign nation. ${ }^{73}$

On appeal, Justice Washington wrote a terse opinion which dealt firmly with the complicated situation. All three ships fell within the statutory prohibition against the taking on board of Negroes "for the purpose of holding, selling, or otherwise disposing of, such person as a slave," 74 since all three had American crew members. After summarily disposing of the jurisdiction problem with a single citation, ${ }^{75}$ he made careful individual rulings for each ship involved, covering each of the slightly different factual and legal situations and throwing out defective counts in the various libels of information ${ }^{78}$ with a technical precision uncommon in Slave Trade Act prosecutions.

The ship owners argued that the statutory policy was "to prevent ... the bringing into bondage those persons who were free in their own country; and, that since the condition of persons already slaves cannot be changed or made worse, by their removal from one slaveholding country to another, the acts of 1800 and 1818 , ought not to be so construed, as to prohibit citizens of the United States being concerned in such removals." "77 At least for American citizens participating in the slave trade, Washington found the purported policy "very questionable" and affirmed the condemnation. ${ }^{78}$ But in inchoate form, the owners' argument raised the question underlying the whole effort against the slave trade: how far could the United States interfere, outside its own waters, with a commerce which was legal in nearby foreign waters?79 In Florida the question was acute, because

73. 22 U.S. (9 Wheat.) at 401-02.

74. Act of Apr. 20, 1818, ch. $90, \S 4,3$ Stat. 450.

75. 22 U.S. (9 Wheat.) at $402-03$.

76. Id. at $403-05$.

77. Id. at 404 .

78. Id. at 405 .

79. The Antelope, 23 U.S. (10 Wheat.) 66 (1825), resolved that question. See note 102 infra. 
one obvious purpose of shipping slaves from Cuba to Florida was to smuggle them across the border into the United States. Washington found a compromise answer of sorts by picking through the facts and charges and finding that, in the case of one of the ships, the cargo of slaves should be restored to the Spanish owner who had legal title under Spanish law, although the slaves of other ships were forfeited to the United States. ${ }^{80}$

Two other elements of The Merino are worth mention. One is the appearance of the private seizor, in this case a Colonel Brooke, who took possession of the Constitution in Pensacola harbor and brought the ship to Mobile, where it was then boarded by a revenue agent. The Slave Trade Acts, along with the Ship Registry Acts and others, provided that anyone who seized and successfully prosecuted a ship for a statutory violation would receive at least half the proceeds following condemnation and sale ${ }^{81}-\mathrm{a}$ device which promoted far better enforcement than the Navy alone could have managed. ${ }^{82}$ The other point is the automatic recitation by Justice Washington that "technical niceties of the common law ... are not regarded in Admiralty [pleading]." ${ }^{83}$ The proposition had a respectable case law history, but in the slave trade area it supplied broad license for courts to tolerate a range of procedural flaws in what were admittedly penal ${ }^{84}$ and essentially criminal proceedings.

The Apollon ${ }^{85}$ was not a slave trade case, but the facts are otherwise similar enough to those in The Merino that a comparison helps to isolate the difference which a slave trade context made to the Court in 1824. The case involved a French ship carrying ordinary cargo to the United States. On arrival off the port of Charleston, the captain discovered that a special punitive duty against French ships had just passed Congress, ${ }^{86}$ and to avoid it he turned south to Amelia Island, just below the mouth of the St. Mary's River which formed the border between Georgia and Florida. Later, on hearing that the Spanish had established a new port of entry on a Spanish tributary

80. See 22 U.S. (9 Wheat.) at 407-08. Justice Washington's solution may prefigure the outcome in the landmark case of The Antelope, 23 U.S. (10 Wheat.) 66 (1825), in which slaves captured by privateers were ordered returned to their original Portuguese owners.

81. See, e.g., Act of Mar. 22, 1794, ch. 11, $\$ 4$, I Stat. 347; Act of May 10, 1800, ch. 51, $\$ 1,2$ Stat. 70 ; Act of Apr. 20, 1818, ch. 91, $\$ \$ 1-4,3$ Stat. 450 . See generally Act of Dec. 31,1792 , ch. 1, \$ 16, 1 Stat. 287.

82. The disposition of the Constitution's cargo of slaves in The Merino indicates some of the possible complications of the system.

83. 22 U.S. (9 Wheat.) at 401.

84. Id. at 403 .

85. 22 U.S. (9 Wheat.) 362 (1824).

86. Act of May 15, 1820, ch. $113, \S \S 4-5,3$ Stat. 605 . 
of the St. Mary's, the Apollon's captain sailed her up-river and entered her at the new port. There, in Spanish territory, she was seized 18 days later by the American tax collector for the nearest American port, who claimed she had evaded the new duty. ${ }^{87}$ By the time the case reached the Supreme Court, the government had conceded that the seizure was unjustifiable (by failing to press an appeal from the district court decree of restitution), and the only question before the Court was a suit for damages.

Like Pensacola, Amelia Island was a well-known trouble spot on the border with Spanish Florida, not because of Indian uprisings but because it was a notorious lair for pirates and privateers. As part of the fight against Spain, some of the revolutionary Latin American governments had given commissions to privateers ${ }^{88}$ to take over coastal territory in Florida to serve as bases for attacks on Spanish shipping, and a Scotsman in 1817, sailing out of Savannah, had succeeded in taking over Amelia Island for that purpose. Naturally, the buccaneers did not limit themselves to Spanish shipping. President Monroe and his Secretary of State, John Quincy Adams, quickly ordered American military and naval forces to invade Amelia Island to drive out the pirates, which they did in December $1817 .{ }^{89}$ The motive was more acceptable than that for Jackson's adventure in West Florida, and the scale was smaller, but the incident still caused diplomatic ripples. It also left the territorial identity of the island in doubt, and the Apollon's captain had prudently inquired at Charleston to make sure Amelia Island was still considered Spanish before he took refuge there in June 1818.

In finding no probable cause for seizure, and therefore upholding the damage award, Justice Story managed also to decide the question of the punitive duty. Of course the Apollon intended to send her cargo into the United States; ${ }^{90}$ indeed her entire voyage since arriving off Charleston had been under the direction of her cargo's American consignee. ${ }^{91}$ But she never intended to enter an American port, and Story held such intent to be a necessary element of the statutory offense; passing through the international waters of the St. Mary's was not enough. ${ }^{22}$ If the Apollon intended to sail her cargo into the United States herself without paying the duty, that would be smuggling, but Story pointed out a perfectly legal alternative: to transfer the cargo

87. 22 U.S. ( 9 Wheat.) at 363-65.

88. For a fuller explanation of privateering arrangements, see p. 784 infra.

89. See generally S. BEMIS, supra note 37 , at 307 .

90. 22 U.S. (9 Wheat.) at 375.

91. Id. at 364 .

92. Id. at 367-72. 
to American or other foreign vessels for the final short step into the United States. Nor would that evade the intent of the statute, since "the expense of the transshipment must have been supposed by Congress to be, in ordinary cases, a full equivalent to the increased duty." The policy of the act was to burden French commerce, not to bar it, and that policy was "as completely effected by compelling French ships to perform circuitous voyages, and thus to incur the disadvantages of transshipments, as by payment of the tonnage duty." 93

Story's attitude toward maritime regulations in a pure revenue context contrasts markedly with his approach when slaves were involved. In The Apollon he wrote,

We cannot enter into political considerations, on points of national policy, or the authority of the government to defend its own rights against the frauds meditated by foreigners against our revenue system, through the instrumentality and protection of a foreign sovereignty. Whatever may be the rights of the government, upon principles of the law of nations, to redress wrongs of this nature, and whatever the powers of Congress to pass suitable laws to cure any defects in the present system, our duty lies in a more narrow compass; and we must administer the laws as they exist, without straining them to reach public mischiefs, which they were never designed to remedy. ${ }^{94}$

Story added:

It would be monstrous to suppose that our revenue officers were authorized to enter into foreign ports and territories, for the purpose of seizing vessels which had offended against our laws. It cannot be presumed that Congress would voluntarily justify such a clear violation of the laws of nations. The arrest of the offending vessel must, therefore, be restrained to places where our jurisdiction is complete, to our own waters, or to the ocean, the common highway of all nations. ${ }^{95}$

Even if smuggling were the purpose, jurisdiction should be strictly observed:

But, admit that he had an intention of illegal trade, how could that intention, not carried into effect within our jurisdiction, afford probable cause of seizure in a foreign territory? ${ }^{36}$

93. Id. at 375. Warren suggests the decision "aided in the maintenance of friendly relations" with France. 1 C. WARREN, supra note 4 , at 581 .

94. 22 U.S. (9 Wheat.) at 366 .

95. Id. at 371 .

96. Id. at 375 . 
Yet Story had no trouble approving the Pensacola seizures in The Merino, though in that case there was no evidence at all of intent to import into the United States. And in his famous 1822 opinion in La Jeune Eugenie, he had implicitly argued for the broadest possible jurisdiction over slave trade offenses, since he was willing to find them illegal under international law. ${ }^{97}$ Though not for the last time, the problem of slavery demanded special interpretations of the law in 1824 .

\section{B. Privateers}

Like some of the slave trade cases, the case of The Monte Allegre ${ }^{98}$ involved a small legal matter irrelevant to, but growing out of, a major international problem: in this case, privateering. ${ }^{90}$ During the War of 1812 the United States had commissioned privateers to capture British merchant ships, and public sentiment ran in favor of the device. Later in the decade the revolutionary governments of Latin America offered commissions against Spanish shipping, which many American adventurers accepted. For a while longer the public overlooked the avarice of the privateers because of sympathy for the revolutionaries, but by 1820 the new governments were well established, and privateering was in disfavor. ${ }^{100}$ Secretary of State Adams, once a believer in "a militia moving upon the water," changed his mind on seeing the abuses of the South American privateers, and he included its abolition in the abortive 1824 treaty with Great Britain. ${ }^{101}$

Although the major revolutionary governments in Latin America restrained their privateers as they established sovereignty, splinter groups of rebels continued to grant commissions with abandon. One such was a group calling itself the Banda Oriental, or Oriental Republic, under the leadership of José Artigas, which claimed an uncertain amount of territory in what is now Uruguay. The signature of Artigas was carried by a number of privateers in both North and South American waters which were still operating after 1821.102

97. United States v. The La Jeune Eugenie, 26 F. Cas. 832 (No. 15,551) (1822).

98. 22 U.S. (9 Wheat.) 616 (1824).

99. "The privateer... was a ship owned and fitted out at private expense for the purpose of preying on the enemy's commerce to the profit of her owners, and bearing a commission, or letter of marque, authorizing her to do so, from the government." $\mathrm{E}$. Maclay, A History of American Privateers 7 (1899).

100. See, e.g., J. Gallison, The Practice of Privateering Considered (1820). See generally 1 C. WhaREN, supra note 4, at 569-86.

101. See generally S. BEMIs, supra note 37, at 305, 346-55, 436.45; 1 C. WarReN, supra note 4 , at 570 \& n.l.

102. One happy coincidence of the 1824 Term is that the facts in its admiralty cases, including The Monte Allegre, anticipate each part of the fact situation in The Antelope, the landmark case in 1825 which determined that slavery was not a violation of inter- 
The Monte Allegre was a Portuguese ship captured in 1818 by an American-owned privateer, La Fortuna, under a commission from the Oriental Republic. ${ }^{103}$ The ship was taken to Baltimore, where it was libelled by the Consul-General of Portugal, appearing on behalf of the unknown Portuguese owner. La Fortuna was found to have violated the neutrality acts which prohibited American ships from attacking ships of any country not at war with the United States, ${ }^{104}$ and the Monte Allegre was ordered returned to the Portuguese Consul-General. The Supreme Court through Chief Justice Marshall affirmed in 1822, in a two-page opinion which clearly settled the illegality of American participation in privateering, under whatever arrangement. ${ }^{105}$

The 1824 case of The Monte Allegre dealt with the judicial sale of the Monte Allegre's cargo under interlocutory order, a common practice where the cargo might otherwise spoil before final disposition of the case. Thomas Tenant, a merchant, bought more than 600 bales of tobacco at the judicial sale, for $\$ 15,500$, and later discovered that it was largely rotten; he sued for damages on an implied warranty. The cause might have seemed minor and the outcome certain, but the Court heard elaborate argument before holding that there were no warranties in judicial sales and rendering judgment of no damages. ${ }^{106}$ In the official report of the case, Wheaton included a disproportionate amount of the arguments of counsel, perhaps because he felt the inadequacy of Justice Thompson's relatively crude and unlearned opinion to explain the outcome. Another curiosity of the case was the appearance of the Attorney General, ${ }^{107}$ arguing against the judicial officer who made the sale and in favor of Tenant. His theme

national law, and hence that American jurisdiction over slave traders was limited. As a result, when the Justices came to consider the very complicated facts in The Antelope the following year, there was relatively little chance of distraction or confusion by the several legal side issues which the complications could have produced.

The Antelope, a Spanish ship loaded with slaves, was captured off Africa by an American privateer from Baltimore, under commission from the Oriental Republic. Under the control of the privateers, and carrying slaves from several other of their prizes as well, the Antelope sailed to Florida. There she was captured, off the coast but outside U.S. territorial waters, by an American revenue cutter, who brought her in to the District Court in Savannah. 23 U.S. (10 Wheat.) at 123-24.

The central issue in the case was whether to return the slaves to their original Spanish and Portuguese owners (actually, again, to the Consuls-General). To reach it, however, Marshall had to cut through the law of privateering and prizes, neutrality, and extraterritorial seizure. He did so in summary fashion, 23 U.S. (10 Wheat.) at 119-123, perhaps because the same issucs had arisen in The Monte Allegre, The Apollon, and The Merino.

103. See The Monte Allegre, 20 U.S. (7 Wheat.) 520 (1822).

104. Act of June 5, 1794, ch. 50, 1 Stat. 381; Act of Apr. 20, 1818, ch. 88, 3 Stat. 447.

105. The Alonte Allegre, 20 U.S. (7 Wheat.) 520 (1822).

106. The cause came up yet a third time in 1826. See Chace v. Vasquez, 26 U.S. (11 Wheat.) 429 (1826).

107. At this time, William Wirt. 
was that the Portuguese Consul-General should not reap a windfall at the expense of an American citizen. Had the rotten tobacco been discovered before sale, the Consul-General would have realized only an estimated $\$ 4,500,{ }^{108}$ with no grounds for complaint. ${ }^{100}$

The case of The Fanny ${ }^{110}$ had nearly the same background as The Monte Allegre: American privateers operating against Portuguese ships under commission from Artigas. These privateers, however, were not caught; they had taken their captured cargo to the Virgin Islands, sold it, and disappeared. The American consul in St. Thomas, Nathaniel Levy, was one of the purchasers-he bought some 4,000 hides from the privateers-and when he shipped them to Baltimore for sale, they were seized as Portuguese property, and so decreed by the district court. ${ }^{111}$ On appeal Levy attacked the disposition of the hides, and a subsidiary question was raised over who should pay the charges for shipping the hides from St. Thomas to Baltimore: Levy or the Portuguese Consul-General, standing in again for the unknown original owner. ${ }^{112}$ Justice Washington delivered a lucid, surehanded opinion which reduced both questions to the issue of good faith purchase by Levy, and remanded the case to the circuit court for better fact finding. The formal decree outlined each possible outcome and virtually guaranteed no further appeals. ${ }^{113}$ Both The Fanny and The Monte Allegre reaffirmed the Supreme Court's consistent position "that the taking of a prize by a ship fitted out or acting in violation of the neutrality of the United States would be held invalid by our Courts, and restitution ... decreed."114

\section{Western Land}

The Supreme Court in 1824 decided a number of cases dealing with what Wheaton ${ }^{115}$ in his official reports classified as "local law."110

108. 22 U.S. (9 Wheat.) at 617.

109. Id. at $638-40$.

110. 22 U.S. (9 Wheat.) 658 (1824).

111. Id. at 659-62.

112. Among other arguments, counsel for Portugal urged that the Oriental Republic was not an acknowledged government at war with Portugal, and hence that the privateers in the case were really pirates (and thus subject to the death penalty). 22 U.S. (9 Wheat.) at 662-63. The Court's agreement would have been a scverc blow to the Artigas revolt, but it ignored the argument in favor of a more modest ratio decidendi. Portugal offered the same argument and got the same response earlier, in The Gran Para, 20 U.S. (7 Wheat.) 471 (1822).

113. 22 U.S. (9 Wheat.) at $672-73$.

114. See I C. WARREN, supra note 4 , at 573 \& n.1.

115. See note 14 supra.

116. Neither Dallas nor Cranch used general subject headings either above the case name or on the index page of the reports. Wheaton inaugurated the former in 14 U.S. (I Wheat.) (1816) and the latter in 15 U.S. (2 Wheat.) (1817). 
The great majority involved questions of land law-either directly, as between competing claimants in an ejectment proceeding, or indirectly, such as in probate. There were 15 such cases; by contrast, there were four negotiable instruments and three contracts cases in the same term. The disproportion may reflect the state of the American economy, in which wealth was primarily in land and not in movables. ${ }^{117}$ In addition, Justice Todd, highly knowledgeable about Kentucky law, had been ill the previous term, and the Court had retained on its docket a number of Kentucky cases. ${ }^{118}$ These frequently involved land grants or property law questions concerning property obtained by a land grant; thus Todd's return in 1824 in part explains the disproportion.

The most important land cases involved various claimants fighting over land which one or both of them claimed under warrants, military or treasury, issued by one of the states or the national government. Large numbers of such claimants held vast amounts of land ${ }^{119}$ whose ownership could have been affected by a Supreme Court decision.

In Doddridge $v$. Thompson ${ }^{120}$ the Court faced a nearly insoluble problem, choosing between competing claims in what was called the Virginia Military Reserve in Ohio. Doddridge cannot be understood apart from the history of the origin of the Reserve and Congress's attempts to develop a national land policy after the adoption of the Constitution in 1789.

From the time of the Royal Proclamation of 1763, which offered "unappropriated crown" lands to those who volunteered to fight for His Majesty's Government in the French and Indian Wars, ${ }^{121}$ the

These local law cases came to the Court under its diversity jurisdiction or under other provisions of the Judiciary Act of 1789 which left the case to be determined under the law of the locale. See, e.g., Hughes v. Edwards, 22 U.S. (9 Wheat.) 489 (1824) (jurisdiction predicated on the plaintiff' alienage pursuant to $\$ 11$ of the Judiciary Act, 1 Stat. 73 , 78-79).

117. It also reflects the commercial depression in the United States following the Panic of 1819. See generally G. DaNGerfield, THE AWAKEning of American Nationalism, 18151828, at 72-96 (1965); M. RóthBARD, The Panic of 1819 (1962).

118. In a letter dated March 14,1823 , to Justice Todd, Justice Story wrote in reference to Todd's illness: "We have all missed you exceedingly during this term, and particularly in the Kentucky Causes, many of which have been continued solely on account of your absence." I W.W. STORY, supra note 58, at 422. In his "Sketch" of Justice Todd written after Todd's death Story said, "In his knowledge of the local law of Kentucky, he was excelled by few; and his brethren drew largely upon his resources to administer that law, in the numerous cases which then crowded the docket of the Supreme Court from that judicial circuit." Miscellanfous Writings of JOSElH STORY 817 (W. Story ed. 1852).

119. The military bounty grants by the federal government alone were numerous and generous. As of 1907 approximately 16,663 warrants had issued in the amount of $2,165,000$ acres of land for revolutionary war service. As of the same date 29,186 warrants had issued in the amount of $4,845,920$ acres of land for service during the War of 1812. B. HiBBARD, A History of Public Land Policies 132 (1999).

120. 22 U.S. (9 Wheat.) 469 (1824).

121. P. Treat, The National Land System 1785-1820, at 230 (1910). 
American colonies had rewarded their veterans with generous grants from the public domain. The Continental Congress offered land first to Hessians who deserted ${ }^{122}$ and later to all men who served in the Colonial Army. ${ }^{123}$ The gifts were in the form of nonassignable warrants that the claimant could present in return for a portion of the public domain. ${ }^{124}$ Such generosity created problems. First, the Continental Congress and later the Confederation and the United States owned no territory; in order to honor the warrants Congress had to depend on the states to supply land.125 Second, since the land was for the most part unsurveyed, Congress's unspecific largesse inevitably produced a welter of conflicting claims. The second problem was remedied in part under the Confederation by the Act of 1785, which required a survey before confirmation of a grant.120

The first problem, lack of land, was resolved by a series of seven deeds of cession between the various states and the national government. In return for ceding their western territorial claims, these states exacted a variety of concessions; the most fateful required the national government to recognize certain "reservations" by the original states of land in the ceded territories.

In 1784 Virginia ceded all of its claims in the West but retained two reserves. The parties understood that these were to be used by Virginia to satisfy claimants who had served either in the Colonial or in the Virginia Army during the Revolution. The smaller of the two was in Kentucky and was to be exhausted before the state could issue warrants redeemable in the second reserve, situated between the Scioto and Little Miami rivers in Ohio. ${ }^{127}$ Unfortunately the deed of cession was hastily drawn. It failed to state that veterans of the Virginia Army were entitled to claim land, it took no account of unexpired Indian claims, and it neglected to delimit the boundaries of the reserves. ${ }^{128}$ Virginia had actually begun to issue warrants in the Ohio reserve before the cession; the reserve was in any case officially opened for federal disposition by statute on August 10, 1790. ${ }^{128}$

After cessions by the states had given the federal government land to honor its military land bounties, Congress passed a series of statutes

\footnotetext{
122. Id. at 231.

123. Id. at 232.

124. Id.

125. Id.

126. Id. at 236 .

127. Id. at 327 .

128. Id. at 328 .

129. Id. at 331 .
} 
that in effect put the excess, including the rest of Ohio, up for sale. ${ }^{130}$ The Act of June 1, 1796, made federal warrants transferable before entry and further provided that warrants had to be presented by January 1,1800 . Later extensions ${ }^{131}$ kept the warrants valid beyond 1824 .

Doddridge $v$. Thompson was one result of the drafting errors in the Virginia cession of 1784 . Both plaintiff and defendant claimed under patents issued by the United States. ${ }^{132}$ Plaintiff's Virginia warrant was older; it had originally been obtained by an officer of the Virginia Army and had, presumably by sale or gift, come into plaintiff's hands. The defendant had purchased his warrant from the United States. The patents, as issued, overlapped. The case was "agreed" in the circuit court which registered a pro forma judgment for the defendant. ${ }^{133}$

The controversy resulted from the cession's failure to delimit the boundaries of the Virginia Military Reserve. The cession said only that "no part of the land included between the rivers called Little Miami and Scioto, on the northwest side of the river Ohio" might be used by the national government until Virginia's military claimants were satisfied.134 One William Ludlow had attempted in 1802 to draw a line connecting the sources of the two rivers; ${ }^{135}$ it later appeared that his line followed a course too far to the east. In 1804 Congress passed a law setting up a procedure to ascertain the boundaries of the reserve. It provided that if Virginia voted to accept Ludlow's line within two years, then land west of that boundary could be sold by the national government. Though Virginia would not accept the line, the national government apparently went ahead anyway and sold land to its west. In the meantime Virginia claimants, including the predecessor of the Doddridge plaintiff, had already received warrants redeemable

130. Congress first required a survey, id. at 236, and then set the terms and conditions for sale, id. at 238 .

131. Id. at 242 .

132. A warrant gave an inchoate right to a certain amount of land. A patent was issued by the responsible administrative authority (in this case the United States because Ohio was a territory) after presentation of a warrant and usually after entry and a survey, which in the case of the Ohio reserve was commissioned and paid for by each claimant. Unlike the federal land there was no organized survey.

133,22 U.S. (9 Wheat.) at 470 . Although today universally repudiated as a collusive device for obtaining a ruling by an appellate court, the pro forma judgment was still in good standing in 1824. The range of cases in which an appellate court would allow the parties in effect to confess a judgment without trial in order to get to the higher court is unclear.

134. B. HibBard, supra note 119, at 122 (1939).

135. Ludlow failed because he ran into land with unexpired Indian claims and probably unexpelled Indian inhabitants. Congress and Virginia had apparently agreed to the dedication of this reserve without negotiating a purchase from these Indians. The whole problem of drawing a line between the origins of the two rivers was further complicated by the fact that source of the Scioto (the easternmost river) was west of the source of the Little Miami, P. TREAT, supra note 121, at 333. 
for any land in the reserve, including, presumably, west of Ludlow's line.

In 1812 Congress made another attempt to solve the problem. ${ }^{136}$ It brought together commissioners of Virginia and the federal government, who hired one Charles Roberts ${ }^{137}$ to draw a line that would connect the sources of the two rivers. He came up with a line to the west of Ludlow's line that would have extinguished the claims of people like the defendant in Doddridge who had paid the government cash for a federal warrant. The two sets of commissioners could not agree even on this line, and things stood as they had before enactment of the statute in 1812.

The plaintiff, the Virginia claimant, relied on the language of the original cession, as interpreted by Roberts's line, while the defendant (federal claimant) attempted to show that somehow Ludlow's line was binding on Virginia. In an opinion that squarely confronts the issue between the two parties, Chief Justice Marshall surprisingly relied on a technicality to decide the case. ${ }^{138}$ Marshall held that in the Act of 1812 Congress had no intention to establish Ludlow's line by fiat; Virginia could have made the line binding by agreement with the federal commissioners, but no agreement was reached. Since Congress did not so intend, it also could not have intended to "annul" valid prior titles, like plaintiff's here. ${ }^{139}$ The Court reversed, holding for the plaintiff on the ground that his Virginia warrant was preeminent because it was older than the defendant's.

Two important characteristics of the case should be noted. ${ }^{140}$ First, Doddridge did not make a final choice between Ludlow's line and Roberts's line; Congress and Virginia were left free to work out a solution. ${ }^{141}$ Second, it gave the immediate victory to the state claimant

136. Id. at 334 .

137. Id. at $334-35$.

138. Marshall properly ignored the fact that in 1818 Congress had voted to establish the Ludlow line as the authoritative line to the old Indian boundary and the Roberts line from the old Indian boundary. Id. at 353. See Act of Apr. 11, 1818, ch. 47, 3 Stat. 423.

139. 22 U.S. ( 9 Wheat.) at 479. Marshall also rejected a hypertechnical argument made by the defendant concerning the Act of March 2, 1807, 2 Stat. 424, which had extended the statute of limitations for making locations. Id. at 480-83.

140. The resolution did provoke congressional action. On April 6, 1824, Rep. Vance of Ohio made a motion, which carried, to appoint a committee "to inquire into the expediency of granting relief to such persons, purchasers of the public lands, lying between Ludlow's and Roberts's lines, in the State of Ohio, as are liable to be evicted from the same, on the principles of a decision of the Supreme Court of the United States, made at their last term, in the case of Doddridge...." 42 ANNALS OF CoNG. 21 '2 (1824). A bill was reported out by the committee, read twice and laid on the table on May 4, 1824. Id. at 2541. A petition by warrant holders was presented to Congress on this matter on May 6 , 1824. Id. at 2551. The bill was read a third time and debated, id. at 2576-78 and passed, id. at 2586 , on May $10,1824$.

141. The eventual solution was that Congress appropriated $\$ 62,515,250$ in 1830 to pay double claimants. P. TREAT, supra note 121 , at 335 . 
at a time when the court's nationalist decisions had provoked resentment. ${ }^{142}$

Doddridge is a dramatic case in that it squarely presented a question of cession interpretation, although the resolution was less than dramatic. Most land cases coming to the Court seemed to involve more mundane questions of property law. In fact, however, under the surface of these cases lay significant issues of western land policy. Kerr v. Devisees of Moon ${ }^{143}$ provides an example. The devisees of Archeleus Moon filed a bill in equity in the Circuit Court for the District of Ohio praying that court to order defendant Kerr to convey "evidences of title" to certain parcels of land to the devisees. The facts in the case were fairly straightforward. At the time of his death Moon held warrants to 4,000 acres of land in the Virginia Military Reserve in Ohio, the same reserve as in Doddridge. Defendant Kerr derived his title through one Robert Price who, it was alleged, held the warrants of Moon as assignee of the devisees of Archibald [sic] Moon. ${ }^{144}$ The Circuit Court of Ohio held that defendant Kerr should convey the property to the devisees and that they must pay him for the cost of locating and surveying the land and for taxes paid while in occupation.

On appeal Kerr argued that the Circuit Court of Ohio had erred in allowing its decision to be governed by the result of a probate proceeding in Kentucky. Justice Washington found this convincing: "It is an unquestionable principle of general law, that the title to, and the disposition of real property, must be exclusively subject to the laws of the country where it is situated ...," in this case Ohio. ${ }^{145}$ The Court reversed and remanded for a decision in accordance with the principles of Ohio law.

Kerr might be viewed as a simple choice of law case. The land was in Ohio; Ohio law should govern. In fact, however, it raises issues of national land policy just as sharply as Doddridge. One of the recurrent issues which Congress and the landed states faced was whether

142. Cohens v. Virginia, 19 U.S. (6 Wheat.) 264 (1821), was fresh in the minds of many in the Old Dominion, and the unrest sparked by Green v. Biddlc, 21 U.S. (8 Wheat.) 1 (1823), was unabated in Kentucky and Congress.

I43. 22 U.S. ( 9 Wheat.) 565 (1824).

144. The devisees alleged that Price's assignments were fraudulent because obtained from the first wife of Moon and her children, who had been disinherited. Moon's will was executed and probated in Fayette County, Kentucky. The clerk's office with the proven copy of Moon's will had burned down in 1802 or 1803 so the devisees had introduced a copy in the Circuit Court. Il. at 568 . In his answer Kerr stated that he was a purchaser for value, that he had taken the warrants, made entry on 3,723 acres and commissioned a survcy.

145. Id. at 570. The quotation from Washington and indeed the attitude of the Court on a number of matters points to the inevitability of the Supreme Court's subsequent decision in Swift v. Tyson, 41 U.S. (16 Pet.) 1 (1842), which held that "general" 'law, rather than the law of the locale, wonld govern divcrsity actions in the federal courts. 
land warrants should be assignable. At first Congress had decided against assignability. Constant pressure from veterans who wanted money more than land led Congress to reverse itself in 1788 and make national bounty warrants transferable. ${ }^{146}$ As a result of this decision, the frontier regions were not quickly settled by hearty veterans, ${ }^{147}$ as it was once hoped, and many of the warrants ended up in the hands of speculators. ${ }^{148}$ After the War of 1812, Congress again made bounty warrants nonassignable. ${ }^{149}$ The transferable revolutionary war warrants continued in circulation through the 1824 term, however, because Congress kept extending the deadline for presentation. ${ }^{150}$

Kerr would never have come up if warrants had not been assignable; Kerr's title was based on an assignment by the alleged devisees to Price. The Court could not change Congress's basic decision in this regard, but its decision in Kerr was at least an attempt to restrict somewhat the litigation that inevitably ensued, given assignable warrants. It was rational from a policy perspective to seek such restriction, but toward that end the Court had to engage in a certain amount of legal irrationality. The devisees argued that warrants were not realty but personalty. ${ }^{151}$ Justice Washington held that warrants were not personalty and that the "subject matter of the devise was land,"152 adding that even if the warrants were personalty they still had to be probated in Ohio. Under the common law, this conclusion was unsupportable; personalty goes with the testator's domiciliary estate, if found with him at his domicile at the time of death. ${ }^{\mathbf{1 5 3}}$

146. P. Treat, supra note 121 , at 238.

147. Id. at 242 .

148. Id. at 245 .

149. Id. at 248 .

150. Id. at 242.

151. 22 U.S. ( 9 Wheat.) at 570.

152. Id. at 571. It is true that contracts to sell a specific piece of land are somewhat different from normal contracts. They are subject to the Statute of Frauds. 3 American LAw of Property \$ 11.3, at 9-13 (A.J. Casncr ed. 1952). If one qualifies under the Statute of Frauds then the vendor is deemed to have a "vendor's lien" and the purchaser's rights are deemed to go to his devisees by a hocus pocus called an equitable conversion. Id. $\$ \$$ 11.26-11.27, at 69-78. Casner cites Langford v. Pitt, 2 P. Wms. 630 (Ch. 1731), as support for the proposition that the purchaser's contract right passes by devise, although in Lessce of Smith v. Jones, 4 Ohio 115 (I829), the contrary was upheld. The thinking behind Langford may have affected the decision on this point in Kerr.

153. The word unsupportable may seem a bit harsh, but the fact is that all the authority is contrary to the Court's opinion on this matter. Justice Story wrote in his treatise on conflicts of law, "It follows as a natural consequence of the rulc, which we have been considering (that personal property has no locality), that the laws of the owner's domicile should in all cases determine the validity of every transfer, alienation or disposition made by the owner, whether it be inter vivos or post mortem." J. STORY, Commentaries on THE Conflicr of LAws, $\$ 383$, at 315 (1834). Story does cite Kerr to support the proposition that if this were realty then the law of situs would govern. Id. $\$$ 435 , at 370 . See generally Wilkins v. Eillet, 76 U.S. (9 Wall.) 740 (1869); Baker v. Baker, Eccles \& Co., 242 U.S. 394 (1917).

In support of his statement on this matter Washington says of Doc v. McFarland, 13 
Although the legal reasoning of Washington's decision is open to attack, the decision does make common sense. With large numbers of assignable warrants outstanding, it was imperative, if Ohio land titles were ever to be settled, that the land warrants be probated in Ohio. This would at least give some notice to people with warrants seeking land to enter. It was a crude registration device, but the Court was not a legislature and it could not order what was really needed: a survey of the Virginia Military Reserve and implementation of a comprehensive registration system.

Washington's decision in Kerr was profoundly influenced by the uproar that had developed as a result of the Court's decision in Green v. Biddle, ${ }^{154}$ decided the previous term. ${ }^{155}$ The Court in Green struck down, as impairing the obligation of contract, a Kentucky law which required a true owner of land, before ejecting an occupant, to indemnify the occupant for improvements the latter made while in possession. ${ }^{150}$ The Court held that this law impaired the contract between Virginia and Kentucky that had been entered when Virginia surrendered its claims to Kentucky, ${ }^{157}$ by curtailing the common law rights that land owners would have had under Virginia law at the time when Virginia had ceded its lands to Kentucky. In the compact Virginia had expressly sought to protect titles created prior to Ken-

U.S. (9 Cranch) 151 (1815), that "it was decided that letters testamentary gave to the executors no anthority to sue for the personal estate of the testator, out of the jurisdiction of the power by which the letters were granted." Cited at 22 U.S. (9 Wheat.) 571 . It is true that there are dicta in Doe to support this statement; it is also true that the square holding in Doe, which Washington ignores, favored parties like the devisees in Kerr. What actually happened in Doe was that the devisees under a Virginia will were permitted to ste in ejectment to oust the defendant from land located in Kentucky even though the will had never been probated in Kentucky. If anything, the holding in Doe cuts against Washington's rigidity in Kerr.

154. 21 U.S. (8 Wheat.) 1 (1823).

155. The same can be said of Marshall's opinion in Stephens v. McCargo, 22 U.S. (9 Wheat.) 502 (1824). Green v. Biddle, 21 U.S. (8 Wheat.) 1 (1823), was first argued in 1821 , and the Supreme Court held the Kentucky statute unconstitutional in an opinion written by Justice Story which was handed down on March 8, 1821. 1 C. WARREN, supra note 4, at 637. That decision is not found in 19 U.S. (6 Wheat.). The state of Kentucky instructed its counscl, Henry Clay, to ask for a reargument and the case was reargued in March 1822. Justice Washington's opinion was not released, however, until February 27, 1823. 21 U.S. (8 Wheat.) at 69 . Warren believes that the decision was held over for political reasons.

1 C. WARREN, supra, at 638.

156. For a full discussion of Green v. Biddle, see 1 C. WARREN, supra note 4, at 637-48.

One of the most disturbing aspects of the case to its Republican opponents was their claim that the majority opinion was supported by only a minority of the Court. Johnson dissented, Marshall did not sit and Todd and Livingston were too ill to participate according to these people. Id. at 640 . This led to a very serious effort to require that some fixed minimum number of Justices adhere to an opinion in order for it to invalidate a state law. The Senate Committec on the Judiciary, chaired by Senator Martin Van Buren of New York, reported a bill on March 11,1824 , that provided that no state law could be voided without the concurrence of five of the seven Justices. The bill was tabled. See id. at $663-65$.

157. 21 U.S. (8 Wheat.) at 91 . 
tucky statehood. The opposing side argued that this compact was not a contract and, in the alternative, that if it were, then it was repugnant to Article I, $\S 10$, Clause 3 of the Constitution since Congress had not consented. The Court rejected both of these contentions; it held that a compact could be a contract and that Congress's vote to admit Kentucky was consent. ${ }^{158}$

Justice Johnson, dissenting in Green, foresaw the problems the Court's decision would create. ${ }^{159}$ The effect of the decision was to make land matters in states like Kentucky incredibly complex. Land located, entered, and granted before statehood would be protected forever by the contract clause, but with respect to other land the Kentucky legislature was free to legislate. In Johnson's words, the decisions left the nation "to float on a sea of uncertainty as to the extent of the legislative power of Kentucky over the territory held under Virginia grants . ..."160

Frontier sentiment strongly favored laws that protected occupants and debtors; thus it was no coincidence that western senators led a renewed drive to curtail Supreme Court power. ${ }^{101}$ The Congress debated several limiting measures in 1824. Green thus did more than complicate Kentucky land law; it resulted in heavy political pressure on the Court to restrain its nationalist proclivities. This pressure undoubtedly played a part in the Court's decision to avoid a decision in Doddridge, to remand in Kerr and to affirm in Stephens $v$. McCargo. ${ }^{162}$

158. Id. at 92 .

159. The only biography of Justice Johnson curiously fails to make sense of the apparent contradictions in his legal thinking. D. Morgan, Justice Williak Johnson: The FIRST DISSENTER (1954). Some of his opinions, including his concurrence in Gibbons $v$. Ogden, are so broad as to wipe out state powers; in other opinions-for example Grecn $\%$. Biddle-he exalted state sovereignty. He was an ardent Republican and any explanation of his inconsistencies would perhaps begin with the proposition that his political connections may have restrained his intellectual proclivities.

160. 21 U.S. (8 Wheat.) at 103. Johnson's dissent in Green recalls his earlier dissent in another important land claims case, Fletcher v. Peck, 100 U.S. (6 Cranch) 87, 143 (1810), which concerned the Yazoo controversy.

161. See 1 C. WaRren, supra note 4, at 653-85.

162. 22 U.S. (9 Wheat.) 502 (1824). According to Warren, the pressure also led the court to hold for a year a decision on another Kentucky statute that favored debtors, which was argued during the 1824 term. In 1825, the Court released its decision. Wayman v. Southard, 23 U.S. (10 Wheat.) 1 (1825). It eviscerated a Kentucky statute which required a plaintiff who obtained an execution to "endorse" on the execution that the tremendously depreciated notes of state banks would be an acceptable form of payment. The Court did not strike down this statute but held that proceedings in the federal courts (such as an execution) were a matter of federal law and therefore the federal courts could contintie as a part of their supervisory functions to insist that all executions be satisfied in specie. The Kentucky courts were still free to apply the law if any plaintiffs were foolish enough to appear in them. See 1 C. WARREN, supra note 4 , at $648-49$.

The Court also delayed Ogden $v$. Saunders, which involved the validity of state insolvency laws and was argued in 1824. Through a series of delays and one reargument the Court did not hand down its decision until 1827. See Ogden v. Saunders, 25 U.S. (I2 Wheat.) 213 (1827). 
Stephens v. McCargo proved what Justice Johnson predicted in his dissent in Green. Once the Virginia claims were frozen in the Devonian amber of the contract clause, litigation multiplied rather than abated. Furthermore, the difficulties of the Court in this sensitive area were compounded by the result in Green; each new case drew the Court deeper into state affairs.

In Stephens, as in Doddridge, the Court found a way to preserve the state law, protect a state claimant, and avoid another confrontation. The facts were complex. The predecessors of Stephens, the appellant and defendant, obtained a treasury warrant to land in Kentucky in accordance with Virginia law. Entry occurred on May 30, 1780, and the holding was confirmed by a grant on March 1, 1784. McCargo and others (respondents-plaintiffs) claimed under two chains of title. ${ }^{103}$ The first chain began with issuance of a preemption warrant ${ }^{104}$ to one Benjamin Harrison on April 26, 1780; entry with surveyor occurred on June 5, 1786, confirmed by grant on February 10, 1789. The second chain began with the entry of Richard Barbour under a valid treasury warrant on May 10, 1780, followed by a survey in 1786 and confirmed by a patent in 1787 .

Marshall's opinion for the Court easily upheld the claims derived from Barbour, since Barbour's entry under a treasury warrant preceded that of Stephens's predecessor. Harrison's successors had a more difficult time and in holding for them Marshall and the Court glossed over a flaw in Virginia land legislation. The Virginia Assembly had periodically extended the time during which a preemption warrant carried superior rights, but through an oversight there was apparently a short gap in the statutes. ${ }^{165}$ Stephens claimed that during this gap his inchoate right to the land (obtained by entry on May 30, 1780, whereas Harrison's successor did not enter until June 5, 1786) had become vested. ${ }^{106}$ Virginia law and the sentiment of the frontier strongly favored the holder of a preemption warrant (Harrison) as against the holder of a treasury warrant (Stephens's predecessor). If there had been no flaw in the legislation the Court could have adopted the popular position by favoring Harrison's successors.

Stephens had one advantage over Harrison. He had obtained his

163. The Court very quickly brushed over the fact that it violated an old rule of equity to combine two claims in one bill. 22 U.S. (9 Wheat.) at 504.

164. Virginia granted precmption warrants to "meritorious individuals, as a reward for the fatigue and hazard encountered in exploring the country." Preemption warrants to a specific tract of land prevented the public sale of that land and gave the holder of a preemption warrant a superior title. Id. at 507 .

165. Id. at 506 .

166. Id. 
patent first, and a prior Supreme Court decision, Hoofnagle v. Anderson, ${ }^{107}$ written by Chief Justice Marshall, had seemed to make prior issuance of a patent conclusive on the question of title. Marshall wrote: "It is not doubted that a patent appropriates land. Any defects in the preliminary steps, which are required by law, are cured by the patent. It is a title from its date, and [is] conclusive against all those whose rights did not commence previous to its emanation."10\$ In Stephens Marshall frankly admitted, "The Court has felt great difficulty on this point," 169 the point being the Hoofnagle precedent. Stephens's patent was prior to McCargo's, but McCargo's preemption warrant was preferred by Virginia law.

Marshall managed to find for McCargo and the preemption warrant by fiat: the legislature of Virginia created Harrison's preemptive right by statute and it had a right to extend it. ${ }^{170}$ The gap apparently had no effect at all. The Court found some support for this holding in Kentucky decisions, ${ }^{171}$ thereby illustrating the difficulty in implementing Green $v$. Biddle. Green apparently held that Virginia law was dominant over the decisions of Kentucky courts. In Stephens, Virginia law controlled, but the Kentucky courts apparently could decide what the Virginia law was.

Not all the land claims cases decided during the 1824 term involved the Virginia cession. ${ }^{172}$ North Carolina's cession (which became the state of Tennessee) contributed its share of litigation. After considerable resistance North Carolina, like Virginia, had ceded its western land claims to the national government by statute in $1789^{173}$ upon the following conditions: State military land bounties had to be honored from the ceded land; "all rights and entries under North Carolina 'grants should be preserved"; ${ }^{174}$ and North Carolina reserved the right to complete all of its grants. ${ }^{175}$ These conditions resulted in a massive legal tangle, particularly after Tennessee was admitted in 1796,176 because North Carolina, Tennessee and the United States

167. 20 U.S. (7 Wheat.) 212 (1822).

168. Id. at 214 .

169. 22 U.S. (9 Wheat.) at 510 .

170. Id. at 512 .

171. Id. at 513 .

172. There was one other Kentucky land claim case not discussed above, Meredith v. Picket, 22 U.S. (9 Wheat.) 573 (1824). The decision is two pages long and the statement of facts is so abbreviated as to render the holding incomprehensible. It appears to have involved a simple question of interpreting the language of the entry. Id. at 574 .

173. Congress accepted the cession on April 2, 1790. P. TREAT, supra note 121, at 343. 174. Id. at 343-44.

175. Id. The pertinent portions of the cession are quoted in Burton's Lessee v. Williams, 16 U.S. (3 Wheat.) 529,535 (1818).

176. P. TreAT, supra note 121 , at 346 . 
were all engaged to some extent in disposing of Tennessee land. ${ }^{177}$ This situation was intolerable; the Supreme Court, led by Justice Johnson (who was to dissent in Green), had therefore attempted to clear up the situation in Burton's Lessee $v$. Williams ${ }^{178}$ in 1818. The Court held that by its deed of cession to the United States, North Carolina had surrendered its right to make grants in Tennessee to the United States. Although Burton did a great deal to prevent North Carolina's interference with Tennessee land, it did not entirely obviate problems like those Green created, as a number of 1824 cases demonstrate.

Danforth $v$. Wear ${ }^{179}$ was probably one of the cases in which a decision had been delayed until Justice Todd's return to the Court. ${ }^{180}$ Danforth, plaintiff in ejectment, claimed under a North Carolina grant land in Tennessee in the possession of Wear. The facts are not clear, but it would seem from Johnson's opinion that the Indian title to at least part of the Danforth grant was unextinguished at the time of the grant. North Carolina had, in Johnson's words, "been sedulous in her efforts to prevent encroachments upon the Indian hunting grounds, and her laws are express and pointed in invalidating entries and grants made within such reservations." 181 The Circuit Court had for this reason refused to admit Danforth's grant in evidence. Johnson rejected this rigidity and pointed out that part of the grant was admittedly in land over which the Indian grant had expired; the grant was therefore at least in part valid. Because of this, the case had to be remanded so that the grant might be admitted and the case reconsidered. ${ }^{182}$ Johnson's decision thus refused to arbitrate between Danforth's warrant from North Carolina and Wear's Tennessee warrant, but it indicated that the validity of Danforth's warrant is to be tested by North Carolina law, thus supporting Green v. Biddle.

The Court's remand of substantially all of the issues in Danforth contrasts with its decision in Love v. Simms' Lessee, ${ }^{183}$ also written by Johnson. Plaintiff and defendant in ejectment claimed title to certain land in Tennessee by virtue of the same North Carolina warrant. Plaintiff's claim was based on a deed to one Allison dated 1795. The deed to defendant's predecessor was stipulated to be two

177. The United States-Tennessce conflicts were resolved by a statute in 1806 under which the United States surrendered its claims to Tennessee property. Id. at 347-50.

178. 16 U.S. (3 Wheat.) 529 (1818).

179. 22 U.S. (9 Wheat.) 673 (1824).

180. "This cause was argued at the last term, and again argued at the present term ..."Id.

181. Id. at 677 .

182. Id. at 680 .

183. 22 U.S. ( 9 Wheat.) 515 (1824). 
years older. ${ }^{184}$ Defendant's claim would ordinarily have prevailed except that under North Carolina law a deed did not pass an estate unless recorded within twelve months of execution.

The resolution of Love involved a consideration of both North Carolina and Tennessee laws. Plaintiff (holding the junior conveyance) relied on a North Carolina law of 1788 that allowed deeds for land in the "west" (beyond the Cumberland Mountains) to be recorded in Hawkins County, which is in the eastern part of Tennessee, rather than in the county in which the land was situated. Plaintiff recorded his deed in Hawkins County in 1797. The defendant (holding the senior conveyance) did not record until 1806 and then in the county, newly created by the State of Tennessee, where the land was situated. In his instructions to the jury the Circuit Court Judge stated that the plaintiff had the better title. Defendant's writ of error challenged this. ${ }^{185}$

The Supreme Court reversed on the ground that the Circuit Court's instruction was error, because at the time plaintiff recorded in Hawkins County in 1797, the special North Carolina recording law was no longer in effect in Tennessee or North Carolina. Johnson's opinion in this difficult case suggests a concern with the practical realities of land ownership on the frontier. In his conclusion Johnson says: "Since the registration in the county where the land lies, and which is the only registration deemed valid in this cause, gave the prior registration to the prior deed, . . . the Court must be adjudged to have erred in its charge upon that subject." 186 Obviously any effective system of land registration depended on recordation in the county of situs. It is plausible that such considerations may have strongly influenced the Court, given the tremendous confusion in Tennessee land titles. ${ }^{187}$

184. Id. at 516 .

185. At issue in the case was whether the North Carolina special recording provision was still Tennessee law when the plaintiff, who relied on it, recorded his deed in 1797. By its terms the Act of 1788 of North Carolina was to expire in 1790. On the other hand Tennessee had passed a law in 1794 which established recording in Tennessee without mentioning the special Hawkins County registration provision. In the years following and before plaintiff's registration in Hawkins County, North Carolina had let its special provision lapse.

186. Id. at 523 .

187. The Court decided another North Carolina-Tennessee land claim case in 1824, Smith v. McIver, 22 U.S. (9 Wheat.) 532 (1824). The plaintiff had made several entries and obtained patents. The defendant, relying on an older North Carolina grant, had brought a number of successful ejectments, each of which was so small as to fall below the Supreme Court's $\$ 2,000$ limit on writs of error. To remedy this the plaintiff brought a bill in equity that covered all the land and amounted to more than $\$ 2,000$. The Court held that since fraud was the gravamen of plaintiff's bill and since fraud was cognizable at law and equity, jurisdiction attached to the first court to hear the matter. In this case the ejectments (at law) came first so the defendant's demurrer was sustained. 


\section{The Local Law Residuum}

The western land cases were but one part, albeit a significant part, of the large mass of "local law" cases. There were in addition other land cases not involving the western land cessions, some negotiable instruments cases, and a few ordinary contract actions. Unlike the western land litigation, which turned primarily on complex questions of statutory interpretation, these cases allowed the Court to sit merely as an appellate trier of fact or a second tier court of equity and law conducting a trial de novo, and the Court handled them with considerably greater facility. ${ }^{188}$ The terrain was no doubt more familiar, and there were more legal sources ${ }^{180}$ to guide their determinations of these traditional questions of law and equity. The issues today seem very abstruse and the effort to understand them hardly seems justified, since for the most part these cases were decided on the basis of arcane and now forgotten rules. However, in 1824 these decisions may well have been among the most important that the Supreme Court rendered, for it was the most esteemed court of equity and law in the nation and its reports were probably more widely available than those of any other tribunal.

Something of the flavor of these cases, now buried in a sarcophagus of dead law is revealed by Mason $v$. Muncaster, ${ }^{190}$ which had been litigated in one form or another twice in the circuit court and once before in the Supreme Court. Mason (the complainant) had filed a bill in equity seeking cancellation of certain promissory notes that

188. Every generalization needs a qualifier, and the case of Kirk v. Smith, 22 U.S. (9 Wheat.) 241 (1824) qualifies the generalization that the Supreme Court handled local law cases with particular facility. Kirk is the longest local law case of the 1824 term, occupying 84 pages. The parties were represented by the cream of the Supreme Court bar, Clay, Webster, Sergeant, and Attorney General Wirt (representing a private party, as he did on several other occasions during the term). Kirk dealt with a 1779 Pennsylvania Act entitlcd, "An Act for Vesting the Estates of the Late Proprietaries of Pennsylvania in this Commonwealth." It was an act of confiscation, and the issue to be decided was the confiscatory reach of the act. In an opinion by the Chicf Justice running 38 pages, the Court illustrated the problems of statutory interpretation without the benefit of any illuminating sources. On one isste, whether the word "adverse" should be understood to modify possession even though not used, the Court in effect inserted a very significant provision into the statute by implication, but the Court refused to modify in a similar manner the content of another term used in the statute, "manor land." In short, the Court's performance was inconsistency personified, and Justice Johnson in a long and vigorous dissent quite properly objected to the Court's subjective result.

189. In Doddridge for example, there were no citations to cases or treatises, whereas in Mason v. Muncaster, 22 U.S. (9 Wheat.) 445 (1824), both the advocates' arguments and the Court's opinion were replete with citations to American and English cases and treatises. 'This comparison may be suspect in that the advocates' arguments are not uniformly summarized in the report. Sometimes, however, when the arguments are completely omitted, an advocate"s name will be footnoted in the following manner: "He cited Foster v. Hodgson, 19 Ves. 184. Cholmondeley v. Clinton, Jac. \& Walk." Hughes v. Edwards, 22 U.S. ( 9 Wheat.) 489 (1824).

190. 22 U.S. (9 Wheat.) 445 (1824). 
he had given to Muncaster and others in their capacity as church wardens after a sale of part of the glebe ${ }^{191}$ to Mason. Mason also sought to have the conveyance set aside on the ground that there was a defect in the title unknown to him at the time of purchase.

The land had been sold by a parish of the Episcopal Church, pursuant to the Court's decree in Terrett $v$. Taylor:102 Mason's primary argument was that the defendants, both in this suit and in Terrett v. Taylor, did not in fact represent the parish of Fairfax, the undisputed owner of the property, but rather an Episcopal congregation of the city of Alexandria (meaning within the District of Columbia), which was only a portion of the old parish of Fairfax. ${ }^{193}$ Since the true owner (the parish of Fairfax) had not been a party to the Terrett suit, they were not bound by it. Further, because the Fairfax parish did not participate in the conveyance, Mason's title was defective. The defect might appear moot since the old parish no longer existed and could no longer make any grants. However, Mason alleged that the successors of one Jennings, who originally granted the land to the parish, could still obtain the property in a suit against Mason as a result of the defect. The circuit court, per Chief Justice Cranch, resolved these matters by finding, after a careful weighing of all the facts, that the Alexandria church was the parish of Fairfax and therefore the parish was bound by Terrett. ${ }^{194}$ As to the threat of a challenge by Jennings's descendents, the court found that Mason was by succession in privity with Jennings and the warranty in the Jennings deed of grant provided Mason with an estoppel against Jennings's descendents. The circuit court therefore dismissed Mason's bill.

The Court affirmed the circuit court's decision and its affirmance is interesting evidence of the scope and nature of appellate review in

191. Glebe is "the land possessed as part of the endowment or revenue of a church or ecclesiastical benefice." BLACK's LAw DictionARY 819 (1968).

192. 13 U.S. ( 9 Cranch) 43 (1815). In Terrett certain parishioners of the parish of Fairfax sued the overseers of the poor of the District of Columbia and the wardens of the parish to compel them to sell land that was wasting. The defendants (wardens and overseers) confessed the bill, but put in answer that the land belonged to the overseers of the poor rather than the parish as a result of certain statutes passed by Virginia. Id. at 44 . In a powerful opinion by Justice Story the Court rejected the defendants' contention on two grounds. First, the act which came the closest to an act of confiscation was not passed by Virginia until after the District of Columbia, where most of the parish and the land in question was situated, was ceded to the national government by Virginia. Second, the Court rejected any notion of a vague escheat or confiscation of such lands on the basis of "the principles of natural justice." Id. at 52. The Court therefore granted the prayer of the bill and decreed that the lands might be sold if the incumbent of the parish agreed. Id. at 54 .

193. Id. at 1048. The city of Alexandria referred to was within the former Virginia portion of the District of Columbia, but is not to be confused with present-day Alexandria, Virginia. The District of Columbia at that time included Alexandria county, now also in Virginia.

194. Id. at 1050. 
1824. There is nothing in the opinion to suggest that the Supreme Court had a copy of the lower court's opinion. Nor is there anything that suggests any deference to the lower court's determination of the factual issues. Although the two courts reached identical factual conclusions, Justice Story's opinion painstakingly considers each piece of evidence relevant to the determination of the main factual issue, that is, whether the church in Alexandria was by itself the parish of Fairfax. ${ }^{105}$

Mason also shows the facility and pleasure with which Story and the Court dealt with matters of equity jurisprudence, as opposed to statutory interpretation. Story confidently began the opinion with a rap at the advocates' knuckles: "Upon the very voluminous pleadings in this case, assuming more the shape of elaborate arguments, than the simple and precise allegation of facts, which belong to Chancery proceedings . ..."196 The opinion also ends on a confident note. Story contradicted one of Mason's subsidiary claims, namely that in Terrett all the parishioners of the parish as cestuis qui trust of the glebe should have been joined to obtain a valid judgment against the parish. ${ }^{197}$ Story correctly pointed out that they were not the beneficiaries of a trust, since the property was owned by a religious corporation and was to be used only for religious purposes. ${ }^{108}$

Mason is a solid representative of the local law cases of the time. They usually turned on technical issues of common law and equity practice, ${ }^{190}$ and in these minor disputes between private litigants, the

195. This is particularly striking in that the author of the lower court opinion was William Cranch, the Supreme Court Reporter from 1801 to 1817.

196. 22 U.S. (9 Wheat.) 445,454 (1824).

197. Id. at 468 .

198. Id. at 463. The Mason sequelae are reported in Muncaster v. Mason, $17 \mathrm{~F}$. Cas. 983 (No. 9920) (D.C. Cir. 1824), and Mason v. Muncaster, 16 F. Cas. 1052 (No. 9248) (D.C. Cir. 1828).

The tone and confidence of the opinion is of course due in part to the intellectual and literary skills of the author, Justice Story. But this cannot be the only reason for the Court's fluency, because Story himself was capable of writing obscure and strained opinions. Story's opinion in a probate land case of the 1824 term, McCreery's Lessee v. Somerville, 22 U.S. (9 Wheat.) 354 (1824), is indicative. In McCreery's Lessee the testator McCreery died in 1814 leaving an incorrectly witnessed will (only two rather than the three witnesses required by Maryland law signed). Somerville claimed as devisee while McCreery (a niece) claimed as intestate taker. The niece's claim would have been barred by the ancient common law because she was claiming through her father (McCreery's brother) who was an alien. The statute of 11 and $12 \mathrm{Wm}$. III, ch. 6, had attempted to change the common law. In a cryptic opinion Justice Story denied the niece the benefit of the statute on the ground that her father (the disabling alien) was alive. Story's argument is strained, although interesting for his indication that statutes which impinge on the common law will be interpreted narrowly.

199. Occasionally, these technical questions disguised major national controversies. For instance the two cases involving on the surface questions of local suretyship law had great implications for the future development of the national revenue collecting bureaucracy. Miller v. Stewart, 22 U.S. (9 Wheat.) 680 (1824); United States v. Fitzpatrick, 22 U.S. (9 Wheat.) 720 (1824). Until the 1824 term the United States had relied on a revenue 
Justices generally followed the teachings of the English chancellors and common law judges.

\section{Banks}

In 1824, the ongoing power struggle between states and the federal government focused briefly on the Bank of the United States, which had been reincorporated in 1816. In 1819 the Ohio legislature tried to drive the Bank from the state by levying a confiscatory ${ }^{200}$ tax on it; the tax went into effect a few months after the Supreme Court had struck down a lesser ${ }^{201}$ tax on the Bank in McCulloch v. Maryland. ${ }^{202}$ When the issue finally reached the Supreme Court five years later as Osborn v. The Bank of the United States, ${ }^{203}$ Ohio was forced to seek a direct overruling of $\mathrm{McCulloch}{ }^{204}$ on a set of facts which made it appear that the state had flaunted the Court's authority. That it would fail was a foregone conclusion. ${ }^{205}$

The awkwardness of Ohio's timing and the fame of McCulloch have tended to distract attention from that state's very real grievances against the federal Bank, and perhaps from its good faith in prosecuting them. ${ }^{206}$ When the Bank appeared in Cincinnati in 1817, and a year later in Chillicothe, Ohio had just begun a legislative reform program to control its own state-chartered banks. The national Bank immediately ignored and violated the new statutes. The proposal to tax the new Bank was first made in the legislature at the end of 1817 , as part of continuing agitation over bank conduct in general, and was finally enacted one month before the McCulloch decision appeared on March 7, 1819. The tax was by no means a challenge or an impertinence to the Supreme Court. Moreover, in 1818 and 1819 a severe recession was under way in the western states, and Ohio state banks desperately trying to hold off bankruptcy were being outdone not only by the superior solvency of the Bank, but also

bureaucracy composed of relatively independent tax collectors who gave a performance bond to the government at the time of taking office. This structure had been established by "An Act for the assessment and collection of direct taxes and internal dutics" passed by Congress in 1813. Act of July 22, 1813, ch. 16, 3 Stat. 22. Both bonds fell and the taxpayers' money was beyond recovery because of very technical failures to comply with local suretyship principles.

200. The tax, $\$ 50,000$ on each branch of the Bank, exceeded the Bank's total dividends for the year 1819. See 22 U.S. (9 Wheat.) at 795.

201. See id. at 868 .

202. 17 U.S. (4 Wheat.) 316 (1819).

203. 22 U.S. (9 Wheat.) 738 (1824).

204. See id. at 765 .

205. See C. HaInes, supra note 17 , at 476 .

206. See Bogart, Taxation of the Second Bank of the United States by Ohio, 17 AM. Hist. REv. 312 , 323 n.51 (1912). 
by its aggressiveness as a collector of debts from those same state banks, whose notes it held. In the preceding boom years the Bank of the United States had behaved as irresponsibly as any; its sudden righteousness in late 1818 , though necessary to its own survival, spread ruin and hatred through the state banking community. ${ }^{207}$ Finally, by April 1819, the Bank was in the position of owning "a large part of Cincinnati" through foreclosures, with over six million dollars more due and owing to it. Of its 25 state competitors, only eight were still able to meet their obligations in specie by midsummer. ${ }^{208}$ Anti-Bank political pressure was therefore intense, coming from farmers hurt by falling prices as well as from the financial community. Nor was the Ohio legislature's choice of retaliatory method unusual; at the time the tax was enacted in February 1819, five other states already had such taxes and the courts of two others had barred non-state banks. ${ }^{209}$ It did not, therefore, occur to the Ohio lawmakers that their tactic might be unconstitutional. ${ }^{210}$

When the McCulloch decision was announced, ${ }^{211}$ the Ohio legislature did not repeal the tax, and when it went into effect on September 1, 1819, Osborn, the state auditor, was "placed in an embarrassing predicament." However, he decided that as a state officer his first duty was to carry out the state laws. Before he could collect the tax he was served with notice that the Bank would seek an injunction against its collection; he was also served with a copy of the Bank's petition in chancery. He ordered collection nevertheless, ${ }^{212}$ and the amount of the tax-\$100,000-was seized at Chillicothe, one day before the actual injunction from the United States Circuit Court was served on Osborn. Two months later, Chief Justice Marshall ordered Osborn

207. Bank credit in Ohio took the form of note issues, which in 1816 and 1817 had been enormous; the state legislature discovered in January 1818 that state banks averaged a specie reserve of only 20 percent to meet demand liabilities. When the Bank of the United States entered the field, its own huge note issues partly displaced the state bank notes, since the U.S. notes fluctuated less and were always convertible in coin.

The Bank of the United States discounted massive amounts of state bank paper, and it conducted itself casually enough that in October 1818 its discounts exceeded the total amount of banking capital in the state. Its reform of its practices began in July 1818, with an order to its Cincinnati branch to collect 20 percent of due balances per month from debtor state banks; then on October 30 , it cut off credit to state banks altogether. See id. at $313-18$.

208. See generally id. at 313-22.

209. The five states were Georgia, Kentucky, Maryland, North Carolina, and Tennessee. New York, South Carolina, and Virginia were also considering the same step. Id. at 320 .

210. Id.

211. The full text of McCulloch was published in Niles' Register, Mar. 20, 1819, at 68 .

212. Osborn carefully sought legal advice as to whether any of the papers served on him constituted an injunction, and was told they did not. Bogart suggests that Osborn was not trying to defy the Court, but only insisting on technical correctness. Bogart, supra note 206 , at 325 n.60. 
and the other officials involved not to dispose of the seized money pending decision, and they obeyed. ${ }^{213}$

In the four and a half years between Marshall's injunction and his final opinion, the Ohio economy improved and the Bank itself no longer raised hackles. ${ }^{214}$ The state's lawyer delivered a surprisingly poor argument, dotted with more sophistry than passion;215 Clay represented the Bank and relied on $M c C u l l o c h .{ }^{210}$ Still, the various counsel at argument and reargument managed to set out quite starkly the federal-state power issue involved.

The result, in Marshall's long opinion, was a sweeping affirmation of federal power in both holding and dicta. Marshall saved the easiest point-the unconstitutionality of the tax-for last, a tactic made possible by the state's order of argument, which Marshall had only to follow. ${ }^{217}$ Before reaching it, he managed greatly to enlarge federal jurisdiction over cases under Article III of the Constitution, and he opened the way for broad federal judicial interference with state policies, despite the Eleventh Amendment prohibition of suits against states in the federal courts.

Marshall's treatment of the Eleventh Amendment caused a prompt and perhaps justifiable outcry. ${ }^{218}$ By limiting the application of the amendment to cases in which a state was a named party, he authorized a range of suits against state officers, such as Osborn, acting in ministerial capacities. Consequently, state officers could be enjoined from carrying out state laws by a federal court. ${ }^{219}$ Without such jurisdiction, Marshall argued, state officials could obstruct federal law with impunity:

Each member of the Union is capable, at its will, of attacking the nation, of arresting its progress at every step ... while the nation stands naked, stripped of its defensive armour . . . .220

With jurisdiction over state officers, of course, the federal government could forestall the application of any state policy felt to impinge on federal rights.

213. See generally id. at 323-24.

214. Id. at 330 .

215. 22 U.S. (9 Wheat.) at 744-95. Despite the quality of the argument, Wheaton faithfully recorded it in full, cither because of the importance of the case or because Marshall's majority opinion follows and refutes the argument point by point. Id. at 828 .

216. 22 U.S. ( 9 Wheat.) at 795-804.

217. See note 215 supra.

218. See C. HAINEs, supra note 17 , at 476.

219. 22 U.S. (9 Wheat.) at 846-59.

220. Id. at 848 . 
Though it caused a smaller stir, Marshall's interpretation of Article III aimed at an even wider expansion of federal hegemony. The Bank had gone to federal circuit court against Osborn under the authority of a provision of the Bank's 1816 charter which allowed it "to sue and be sued in all State Courts having competent jurisdiction, and in any Circuit Court of the United States"; ${ }^{221}$ the question on which the Court asked for reargument was the constitutionality of that provision under Article III. ${ }^{222}$ Ohio's lawyers claimed that the case was not one "arising under the constitution and laws of the United States," and that the test should be whether the cause, rather than the party, arose under federal law. ${ }^{223}$ In lordly style, Marshall ruled that the Bank's 1816 charter alone was enough to turn every case, even every contract, involving the Bank into one "arising under" federal law, no matter what the dispute.

[The Bank] can acquire no right, make no contract, bring no suit, which is not authorized by a law of the United States. It is not only itself the mere creature of a law, but all its actions and all its rights are dependent on the same law. Can a being, thus constituted, have a case which does not arise literally, as well as substantially, under the law?221

Though he dealt with the counterarguments of counsel, Marshall had no response to the shrewder observation of Justice Johnson in dissent. Johnson pointed out that the decision opened the way for Congress to give federal courts jurisdiction over any kind of actions it chose; all contracts, for example, could be made to arise under federal law simply by passing a law requiring all contracts to be written on paper bearing a federal stamp. ${ }^{25}$ The chance was small, but the power existed.

Osborn gave Marshall an ideal case and set of arguments on which to build new federalist doctrine, and he took full advantage, even distorting the hapless counsel's argument for better effect. ${ }^{226}$ In con-

221. Id. at 805 .

222. Id. at 804 .

223. Id. at $811-14$.

224. Id. at 823 .

225. Id. at 874 .

226. Marshall delivered some of the strongest language of his opinion against a straw man which, according to Johnson, defense counsel never raised. Compare id. at 884 with id. at 819-23. Nonetheless the opinion has been widely praised. Charles Warren, for one, said that "the mighty reasoning of the Chief Justice" caused the eventual defeat of the various anti-Supreme Court proposals then pending in state legislatures. Warren, Legislative and Judicial Attacks on the Supreme Court of the United States-A History of the Twenty-fifth Section of the Judiciary Act, 47 AM. L. REv. 1 (1913). See p. 772 supra. 
trast, Johnson's dissent was sober and restrained. Johnson praised the Bank and agreed that it should be kept strong. He also divorced himself from the main ideological battle by a strong statement in favor of the Supreme Court's appellate jurisdiction over state court judgments. ${ }^{227}$ His complaint was only with the proliferation of direct federal jurisdiction which Marshall's Article III construction would breed. Johnson took the reasonable position that "arising under" referred to the law of the case, not the party, and that there was no need for federal jurisdiction unless a construction of federal law was at stake in a given case. 228

Marshall and Johnson also split over a similar issue in Osborn's companion case, Bank of the United States v. Planters' Bank of Georgia. ${ }^{229}$ The United States Bank had sued on a Georgia bank note which had been endorsed to it by a Georgia citizen; the case therefore fell outside the limits of diversity jurisdiction under $\S 11$ of the Judiciary Act of $1789 .{ }^{230}$ Following Osborn, Marshall held that the 1816 Bank charter nonetheless permitted the Bank to sue the Georgia bank in federal court. As Johnson accurately pointed out, Marshall had in effect repealed the Judiciary Act's diversity provisions, at least as to the Bank of the United States. ${ }^{231}$

It was in the foregoing context $\mathrm{t}^{232}$ that the Supreme Court decided

227. 22 U.S. (9 Wheat.) at 886.

228. Id. at 887-88. Johnson expressed his view as early as 1801. See State v. Pitman, 1 S.C. (1 Brevard) 32, 34 (1801).

229. 22 U.S. (9 Wheat.) 904 (1824).

230. Id. at 908-09.

231. Id. at 913 .

232. The 1824 term also includes a number of cases which the Justices found worthy only of short, even peremptory opinions. In importance, the underlying issues range from trivia to life and death; in complexity, from the merest quibble about certiorari process, Stewart v. Ingle, 22 U.S. (9 Wheat.) 526 (1824), to the opening round of a 25 -year litigation, Walden v. Craig, 22 U.S. ( 9 Wheat.) 576 (1824). Of these minor companions to the cases discussed above, two have a certain historical piquancy.

Riggs v. Tayloe, 22 U.S. (9 Wheat.) 483 (1824), was a simple contract action which, in the hands of Justice Todd, required only a reiteration of the already well established best evidence rule. What makes the opinion noteworthy is its authorship: it was one of only 11 majority opinions Todd wrote in his 19 years on the Court, and the only majority opinion he ever wrote on any subject other than his specialty, land law. See Israels, Thomas Todd, in LIVEs of THE Justices, supra note 3 , at 408-10. Unfortunately, his excursion into the field of evidence only proved the wisdom of his earlier reticence. His ruling in Riggs was so inappropriate to the facts that it required Chief Justice Marshall to unscramble matters four years later and give directions for a new trial. See Tayloe $v$. Riggs, 26 U.S. (1 Pet.) 591 (1828).

The Court's opinion in Ex parte Burr, on the other hand, deserves attention as perhaps the most delicate and judicious statement of the term, in the face of extraordinary provocation. An attorney named Levi Burr, admitted to the bar of the United States Circuit Court in the District of Columbia in 1822 , had by 1823 been suspended from practice for 
Gibbons v. Ogden. The case had been pending and put off for years; ${ }^{233}$ the decision, when it finally came, met almost unanimous acclaim. The steamboat monopoly was thoroughly unpopular, and the Court found itself in the unfamiliar position of being applauded by members of all political parties for asserting federal power. The fame of the decision was as instant as it has been enduring:234 the news was approvingly reported in papers across the country, and people celebrated with steamboat parties as far away as Georgia. ${ }^{235}$

As he did in Osborn, Marshall found in Gibbons a case where his chosen result was impossible to gainsay (in Osborn because the law was clear, in Gibbons because the outcome was so widely desired) and took full advantage of the chance to make extraordinary new policy in dicta. The immediate rather than the long range consequences were what captured public attention, even within the legal profession; still, in a year when the Court was being harshly attacked for its federalism and seriously threatened with the removal of its jurisdictional power over state law, Marshall might have been expected to compromise and lie low. Instead, he managed to deliver two of the most expansive interpretations of federal power in the history of the Court.

If any single case forestalled the drive to repeal $\S 25$ of the Judiciary Act, it was Gibbons, which taught politicians as well as constituents the virtues of federal review of state court judgments. Gibbons may also have dimmed the chances of the two companion pro-

literally dozens of incidents of champerty, obstructing justice, suborning perjury, and fraud. See e.g., Ex parte Burr, 4 F. Cas. 791 (No. 2186) (1823). After admitting several of the incidents and raising largely procedural defenses in the disbarment proceeding, Burr had the temerity to petition the Supreme Court for mandamus to overturn his suspension. Marshall soberly considered the law of mandamus and the conflicting interests involved, and he met Burr's technical point on its own terms before denying the motion. 22 U.S. (9 Wheat.) at $530-31$. The opinion focuses strictly on the abstract problem of judicial discretion in disbarment; there is no hint of the scurrilousness of Burr's behavior or the insolence of his appeal. 22 U.S. (9 Wheat.) 529 (1824).

There are few conclusions to be drawn from the minor cases of 1824 , but one observation is inescapable: the Chief Justice bore as disproportionate a share of the burden in small matters as in great ones, both in mastering the law and in writing opinions. For example, he made jurisdictional law not only on a grand scale in Osborn and Planters" Bank, but also incrementally in six lesser cases as well. Peyton v. Robertson, 22 U.S. (9 Wheat.) 527 (1824); Smith v. M'Iver, 22 U.S. (9 Wheat.) 532 (1824); Mollan v. Torrance, 22 U.S. (9 Wheat.) 537 (1824); Walden v. Craig, 22 U.S. (9 Wheat.) 576 (1824); M'Iver v. Wattles, 22 U.S. (9 Wheat.) 650 (1824); Ex parte Burr, 22 U.S. (9 Wheat.) 529 (1824). Whether he felt it his duty as Chief Justice or his prerogative, Marshall dominated the Court in the range of issues he covered and the frequency with which he explained them.

233. In 1822 Justice Story wrote to a fellow Justice of his regret that Gibbons v. Ogden would have to be decided: "We have already had our full share of the public irritations, and have been obliged to decide constitutional questions, which have encountered much opposition ..." G. DunNe, supra note 2, at 214 .

234. Marshall's biographer called Gibbons "that opinion which has done more to knit the American people into an indivisible Nation than any other one force in our history, excepting only war," 4 A. BEveridge, LIFE of John MARshall 429-30 (1919).

235. See generally 1 C. WARREN, supra note 4, at 609-16. 
posals-to require a five-vote majority to declare state laws unconstitutional, and to require seriatim opinions ${ }^{236}$-since neither would have availed in the case. At the start of his concurrence Justice Johnson made a statement of support for the seriatim method, ${ }^{237}$ but in fact his opinion demonstrated that the existence of more than one opinion on the majority side need not confuse the issue or dilute the holding. Johnson's vote with the majority was also a near guarantee that there were no hidden dissenters waiting to be flushed out by the delivery of seriatim opinions; ${ }^{238}$ if anyone would have dissented on this question, he would have. Indeed there is some evidence that Marshall's opinion, far from being a monolith, was in fact a collaboration with Justice Story. ${ }^{230}$

A final fortuity of Gibbons was the timing of its decision. Had it been argued in any other week from 1806-1843, a Justice with a clear conflict of interest in the case would probably have cast a vote. Justice Brockholst Livingston, who died in 1823, was a cousin of one of the steamboat monopoly's founders; ${ }^{240}$ his successor, Justice Thompson, was a brother-in-law of the same person. ${ }^{241}$ Ethics of the time would not have prevented either from participating in the controversy, and in fact Thompson had already done so with a pro-monopoly opinion in a lower court. ${ }^{242}$ But Thompson took his seat in 1824 one week late, and Gibbons preserved itself untainted for later, more sensitive generations.

Based on the Supreme Court's work in 1824, it would be unjustified to generalize about the law of the period, particularly where, as here, there has been no effort to show what followed. The cases have not even the reliable randomness of a core sample of judicial work, since their closeness in time to one another and their collection in one volume by an intelligent reporter undoubtedly give them an artificial unity. If any, their virtue is that they are cases old enough that-except perhaps for Gibbons and Osborn-practicing lawyers can regard them without practical interest.

236. See p. 772 \& note 21 supra.

237. "Mr. Justice JoHnson. The judgment entered by the Court in this cause, has my entire approbation; but having adopted my conclusions on views of the subject materially different from those of my brethren, I feel it incumbent on me to exhibit those views." 22 U.S. (9 Wheat.) at 222-23.

238. See note 21 supra.

239. See 1 C. WARREN, supra note 4 , at 608.

240. Dunne, Brockholst Livingston, in LIVES OF THE Justices, supra note 3, at 389.

241. I C. WARREN, supra note 4 , at 607 .

242. Livingston v. Van Ingen, 9 Johns. R. 507 (1812), 15 F. Cas. 697 (No. 8420) (1811). 


\section{The Yale Law Journal}

Volume 84, Number 4, March 1975

\author{
David A. Martin \\ Editor-in-Chief \\ W. Duane Benton \\ Managing Editor \\ R. Hale Andrews, JR. \\ Philip C. BobbitT \\ Laura J. Corwin \\ Alan B. Loughnan \\ Article \& Book Review \\ Editors
}

MARK I. LeVY

Executive Editor

ANDREw H. CoHN

Note \& Project Editor

Holly E. Kendig

Charles H. Montange

STEPHEN R. MYsLiwiec

Lewis T. Stevens

JoHN P. WHEELER III

Note Editors
Paul G. Abrams

Samuel A. Alito

Ned T. Ashby

LON S. BABBY

JOSEPH J. BIANCO

RoY L. Brooks

MARC L. Brown

George F. Carpinello

N. George Daines III

Brett DeHaven

SANFord B. Ferguson

Peter Feuerle

William A. Fletcher

William J. Genego

Ruth N. Glushien

Peter D. Goldnerger
STEven J. Goode

MARK D. HofFer

JOSEPH ISENBERGH

Thomas H. Jackson

VICKI C. JACKSON

Peter R. Jarvis

Ellen A. Kandoian

Diane S. Kaplan

EDWARD D. Kleinbard

MAdeleINe A. KLEINER

Terry S. Kogan

ANTHONY T. KRONMAN

Paul C. Lembesis

Richard B. LEVIN

WALTER P. LOUGHLIN

OWen E. MAcBride
Elliot E. MaXwell

James D. Miller

JUdith A. MILler

Edward R. MulleR

Charles A. Patrizia

Jan-Anders Paulsson

GEORGE K. RAHDERT

JEFFrey L. SCHULte

ROBERT M. SMIITH

John W. SPIEgel

JoNathan W. STILL

Michael L. Tabak

HaRley J. Williams

ROBERT G. WOODWARD

EDWARD A. ZELINSKY

RICHARD M. ZUCKERMAN

Secretaries to the Editors M. Olive Butterfield, Pamela WillmotT

\section{Student Contributors to This Issue}

William J. Genego, Peter D. Goldberger, and Vicki C. Jackson, Parole Release Decisionmaking and the Sentencing Process

Edward D. Kleinbard, Going Private

Thomas H. Jackson, Giving Substance to the Bonus Rule in Corporate Reorganizations: The Investment Value Doctrine Analogy 